\title{
A Comparative Study of $\mathrm{N}_{2} \mathrm{O}$ Formation during the Selective Catalytic Reduction of NOx with $\mathrm{NH}_{3}$ on Zeolite Supported Cu Catalysts
}

\author{
Hai-Ying Chen ${ }^{1} *$, Zhehao $\mathrm{Wei}^{2}{ }^{2} \dagger$, Marton Kollar $^{2}$, Feng $\mathrm{Gao}^{2}$, Yilin Wang ${ }^{2}, \mathrm{Janos} \mathrm{Szanyi}^{2}$, and \\ Charles H.F. Peden ${ }^{2} *$ \\ ${ }^{1}$ Emission Control Technologies, Johnson Matthey Inc. Wayne, PA 19087 (USA) \\ ${ }^{2}$ Institute for Integrated Catalysis, Pacific Northwest National Laboratory, Richland, WA 99352 \\ (USA) \\ *chenh@jmsua.com and chuck.peden@pnnl.gov
}

$\dagger$ Present address: Emission Control Technologies, Johnson Matthey Inc., Audubon, PA 19403 (USA)

\begin{abstract}
A comparative study was carried out on a small-pore $\mathrm{Cu}-\mathrm{CHA}$ and a large-pore $\mathrm{Cu}-\mathrm{BEA}$ zeolite catalyst to understand the lower $\mathrm{N}_{2} \mathrm{O}$ formation on small-pore zeolite supported $\mathrm{Cu}$ catalysts in the selective catalytic reduction (SCR) of $\mathrm{NOx}$ with $\mathrm{NH}_{3}$. On both catalysts, the $\mathrm{N}_{2} \mathrm{O}$ yield increases with an increase in the $\mathrm{NO}_{2} / \mathrm{NOx}$ ratios of the feed gas, suggesting $\mathrm{N}_{2} \mathrm{O}$ formation via the decomposition of $\mathrm{NH}_{4} \mathrm{NO}_{3}$. Temperature-programmed desorption experiments reveal that $\mathrm{NH}_{4} \mathrm{NO}_{3}$ is more stable on $\mathrm{Cu}-\mathrm{CHA}$ than on $\mathrm{Cu}-\mathrm{BEA}$. In situ FTIR spectra following stepwise $\left(\mathrm{NO}_{2}+\mathrm{O}_{2}\right)$ and $\left({ }^{15} \mathrm{NO}+\mathrm{NH}_{3}+\mathrm{O}_{2}\right)$ adsorption and reaction, and product distribution analysis using isotope-labelled reactants, unambiguously prove that surface nitrate groups are essential for the formation of $\mathrm{NH}_{4} \mathrm{NO}_{3}$. Furthermore, $\mathrm{Cu}-\mathrm{CHA}$ is shown to be considerably less active than $\mathrm{Cu}-\mathrm{BEA}$ in catalyzing NO oxidation and the subsequent formation of surface nitrate groups. Both factors, i.e., (1) the higher thermal stability of $\mathrm{NH}_{4} \mathrm{NO}_{3}$ on $\mathrm{Cu}-\mathrm{CHA}$, and (2) the lower activity for this catalyst to catalyze NO oxidation and the subsequent formation of surface nitrates, likely contribute to the higher SCR selectivity with less $\mathrm{N}_{2} \mathrm{O}$ formation on this catalyst as compared to $\mathrm{Cu}-\mathrm{BEA}$. The latter is determined as the primary reason since surface nitrates are the source that leads to the formation of $\mathrm{NH}_{4} \mathrm{NO}_{3}$ on the catalysts.
\end{abstract}


Keywords: Selective catalytic reduction of NOx; Zeolite supported Cu catalysts; Surface nitrate groups; $\mathrm{N}_{2} \mathrm{O}$ formation mechanisms; $\mathrm{NH}_{4} \mathrm{NO}_{3}$ decomposition; Pore restriction effect in zeolites. 
Graphical Abstract

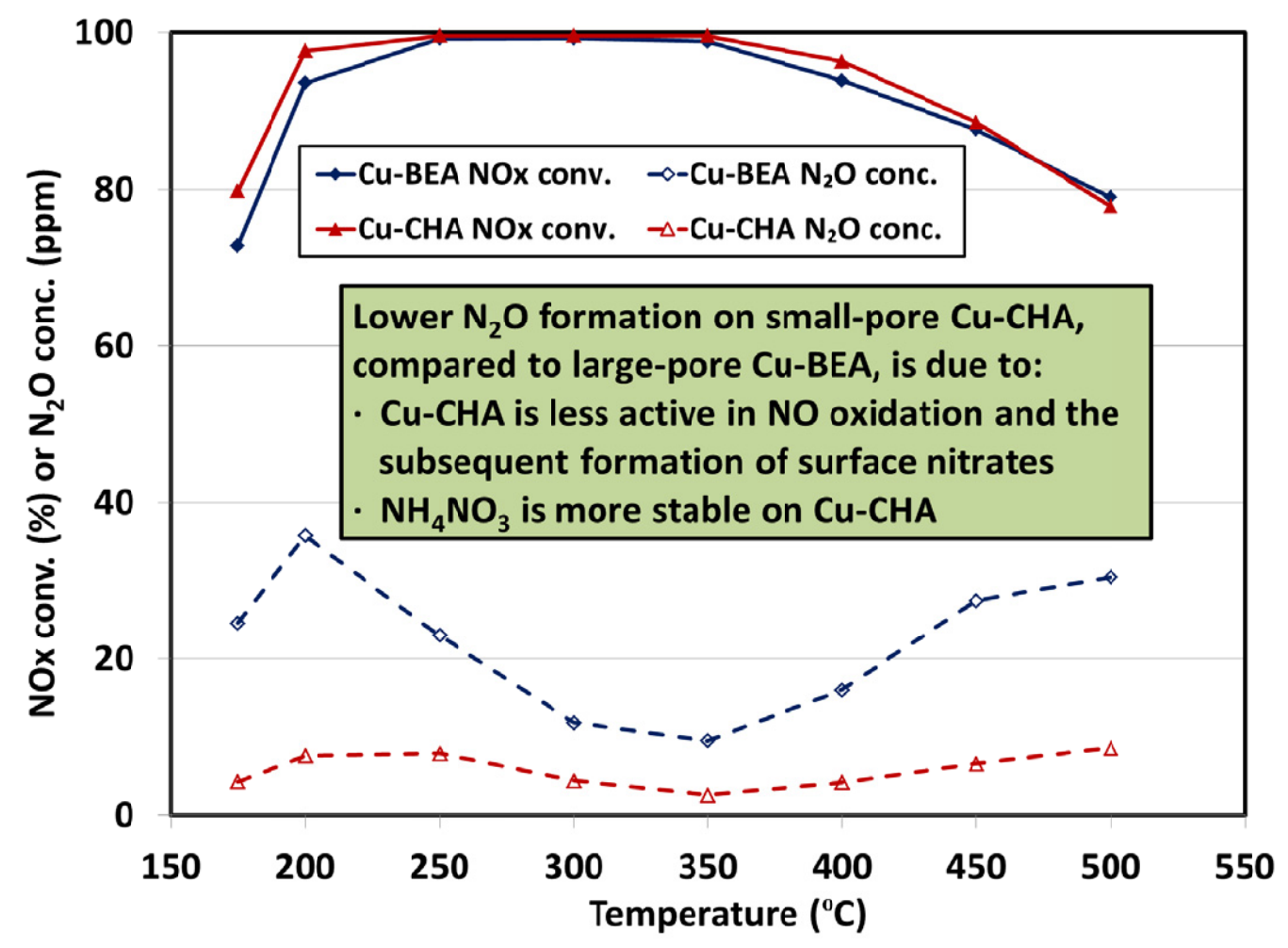




\section{Introduction}

Zeolite supported $\mathrm{Cu}$ catalysts have been found to be active for the selective catalytic reduction (SCR) of nitrogen oxides (NOx) with $\mathrm{NH}_{3}$ since the 1970s [1-4]. Most of the zeolite supports evaluated in earlier work were based on 12-membered ring (large-pore) zeolites, such as BEA, FAU, and MOR [5-11], or 10-membered ring (medium-pore) zeolites, such as MFI and FER [11-13]. It was only recently that 8-membered ring (small-pore) zeolites, such as CHA, AEI, AFX, were recognized to have significant advantages including (1) higher SCR activity; (2) improved hydrothermal stability; (3) better hydrocarbon tolerance; and (4) enhanced $\mathrm{N}_{2}$ selectivity with less $\mathrm{N}_{2} \mathrm{O}$ formation, as compared to large- or medium-pore zeolite catalysts [1, 2, 14-19].

The improvement of hydrocarbon tolerance on small-pore zeolite supported $\mathrm{Cu}$ SCR catalysts can be readily attributed to a molecular sieving effect; in particular, the openings in the small-pore zeolite supports $(\sim 4 \AA$ ) are smaller than the kinetic diameters of most hydrocarbons. It restricts large hydrocarbons from entering the pores of the catalysts where the SCR reactions take place, minimizing the HC inhibition effect on SCR activity. In contrast, the openings in large- or medium-pore zeolite supports are large enough to allow most hydrocarbons to enter their pores, which can severely inhibit the SCR activity of the catalysts $[1,14,20]$.

Pore size effects have also been proposed to explain the improved hydrothermal stability of small-pore zeolite supported Cu SCR catalysts. Dealumination of the zeolite supports and formation of $\mathrm{CuAl}_{2} \mathrm{O}_{4}$-like compounds have been identified as two major causes of catalyst deactivation when zeolite supported $\mathrm{Cu}$ SCR catalysts are exposed to high temperatures in the presence of steam [21-25]. Fickel et al. [15] suggested that the small pore openings in a CHA zeolite restrict migration of the dealumination product $\mathrm{Al}(\mathrm{OH})_{3}$, thus slowing down the 
dealumination process of the zeolite support. Using an in situ XRD technique, Blakeman et al. [20] demonstrated that the undesirable $\mathrm{Cu}-\mathrm{Al}$ interactions were minimized in a small-pore $\mathrm{Cu}$ CHA catalyst, concluding that this was mainly due to pore restriction.

The enhancement of SCR activity and the simultaneous reduction in $\mathrm{N}_{2} \mathrm{O}$ formation on small-pore zeolite supported $\mathrm{Cu}$ catalysts are less well understood. Several groups have reported that $\mathrm{N}_{2} \mathrm{O}$ formation on $\mathrm{Cu}$-zeolite SCR catalysts follows the order of small-pore < medium-pore $<$ large-pore zeolites [1, 18, 19]. The fundamentals on such a trend, however, have not been established. Furthermore, because of its potent greenhouse effect, $\mathrm{N}_{2} \mathrm{O}$ emissions from transportation sources have recently been regulated by government agencies. Thus, understanding of the $\mathrm{N}_{2} \mathrm{O}$ formation mechanisms on zeolite supported $\mathrm{Cu}$ SCR catalysts is of both fundamental importance and practical relevance.

In the present study, two $\mathrm{Cu}$ SCR catalysts with nearly identical compositions, one supported on a small-pore CHA zeolite and the other on a large-pore BEA zeolite, were compared for their $\mathrm{N}_{2} \mathrm{O}$ formation under various SCR reaction conditions. In situ FTIR and temperature-programmed desorption (TPD) in combination with isotope labelling techniques were applied to study the nature of the surface complexes upon NOx adsorption, their reactivity, and their contribution to $\mathrm{N}_{2} \mathrm{O}$ formation.

\section{Experimental}

\subsection{Catalyst preparation}

The small-pore CHA and the large-pore BEA zeolite samples used in this study have the same $\mathrm{SiO}_{2}$ to $\mathrm{Al}_{2} \mathrm{O}_{3}$ ratio ( $\mathrm{SAR}$ ) of 25 . XRD measurements confirmed that both materials are phase pure. $\mathrm{Cu}-\mathrm{CHA}$ and $\mathrm{Cu}-\mathrm{BEA}$ catalysts were prepared by ion-exchange of $\mathrm{Cu}$ into the 
corresponding zeolite supports and the $\mathrm{Cu}$ loading was $3 \mathrm{wt} \%$ for both samples. After ion exchange, the samples were first calcined at $550{ }^{\circ} \mathrm{C}$ for $2 \mathrm{~h}$ in air. To ensure consistent and reproducible results during the study, the calcined powder samples were further hydrothermally treated at $650{ }^{\circ} \mathrm{C}$ for $4 \mathrm{~h}$ in synthetic air containing $5 \% \mathrm{H}_{2} \mathrm{O}$. Such a pretreatment condition was sufficient to stabilize the performance of the catalysts, but remained mild enough in order not to cause appreciable deactivation to either of the catalysts.

\section{$2.2 \quad$ SCR activity testing}

Powder samples of the pre-treated $\mathrm{Cu}-\mathrm{CHA}$ and $\mathrm{Cu}-\mathrm{BEA}$ catalysts were pressed, crushed, and sieved. Samples with particle sizes ranging from 0.251 to $0.422 \mathrm{~mm}$ were selected for SCR activity testing. $45 \mathrm{mg}$ of the coarse catalysts were loaded into a $1-\mathrm{cm}$ diameter quartz tube reactor. The feed gas composition was regulated by the mass flow controllers of each individual gas line. The total flow rate was maintained at $300 \mathrm{sccm}$, which resulted in a gas hourly space velocity (GHSV) of $200,000 \mathrm{~h}^{-1}$ based on the packing density of the catalysts at $\sim 0.5 \mathrm{~g} / \mathrm{cm}^{3}$. Concentrations of the feed gas and products were measured by an online Nicolet Magna 560 spectrometer equipped with a 2-m gas cell that was maintained at $150^{\circ} \mathrm{C}$. Standard SCR activity testing was carried out in a feed of $350 \mathrm{ppm} \mathrm{NO}, 350 \mathrm{ppm} \mathrm{NH}_{3}, 10 \% \mathrm{O}_{2}, 2.5 \% \mathrm{H}_{2} \mathrm{O}$, and balance $\mathrm{N}_{2}$. Steady-state $\mathrm{NOx}$ conversions and $\mathrm{N}_{2} \mathrm{O}$ formation levels were measured in the temperature range of $175-500{ }^{\circ} \mathrm{C}$. In addition, $\mathrm{N}_{2} \mathrm{O}$ formation as a function of $\mathrm{NO}_{2} / \mathrm{NOx}$ ratio was measured at 200 and $350{ }^{\circ} \mathrm{C}$. In these tests, the total $\mathrm{NOx}\left(=\mathrm{NO}+\mathrm{NO}_{2}\right)$ concentration was maintained at $350 \mathrm{ppm}$, and the concentrations for other feed components were maintained the same as shown above for the standard SCR testing. Prior to each testing, the catalysts were pre-treated at $500{ }^{\circ} \mathrm{C}$ for $30 \mathrm{~min}$ in a feed of $10 \% \mathrm{O}_{2}, 2.5 \% \mathrm{H}_{2} \mathrm{O}$ and balance $\mathrm{N}_{2}$ to clean their surfaces. For the experiments performed at $200{ }^{\circ} \mathrm{C}$ and high $\mathrm{NO}_{2} / \mathrm{NOx}$ ratios $(\geq 0.5)$, accumulation of deposits on 
the catalysts was observed. Under these circumstances, additional TPD experiments were carried out after the SCR activity testing. For these, the feed gas was switched to $10 \% \mathrm{O}_{2}, 2.5 \% \mathrm{H}_{2} \mathrm{O}$ and balance $\mathrm{N}_{2}$ and after a 2 min purge, the samples were heated from 200 to $500{ }^{\circ} \mathrm{C}$ at a ramping rate of $25^{\circ} \mathrm{C} / \mathrm{min}$.

\subsection{In situ FTIR and TPD measurements}

The in situ transmission FTIR and TPD measurements were conducted using the same apparatus described in detail in reference [26]. About $4 \mathrm{mg}$ of powder sample was pressed onto a tungsten mesh and mounted in a static IR cell placed in the sample compartment of a Bruker Vertex 80 spectrometer. The cell is connected to a gas manifold and an ultrahigh vacuum chamber with a mass spectrometer. The cell can be isolated from the vacuum chamber by a gate valve and can be pressurized to sub-atmospheric pressures for chemisorptive FTIR experiments, or used as a static reactor. Reactions were monitored by leaking the gas mixtures in the cell into the vacuum chamber though a leak valve. After reactions, the cell was evacuated. TPD measurements were subsequently carried out with the gate valve fully open to increase the signal intensity.

The samples were first heated under vacuum $\left(\mathrm{P}<1 \times 10^{-7}\right.$ Torr $)$ at $500{ }^{\circ} \mathrm{C}$ for $2 \mathrm{~h}$ to clean the surfaces. Such a treatment also caused an auto-reduction of a portion of $\mathrm{Cu}^{2+}$ to $\mathrm{Cu}^{+}$in the catalysts. The samples were then cooled and held at $200^{\circ} \mathrm{C}$. Oxygen was subsequently admitted into the IR cell until the pressure reached 1.5 Torr. This partially re-oxidizes the catalysts. After 30 min of oxygen exposure, the cell was again evacuated and background spectra of the pre-

treated samples were recorded by averaging 256 scans at a $4 \mathrm{~cm}^{-1}$ resolution. The samples were pre-treated according to these procedures prior to any of the gas exposure experiments. 
For the first set of $\left(\mathrm{NO}+\mathrm{O}_{2}\right)$ adsorption experiments, a mixture of $(0.15$ Torr $\mathrm{NO}+1.35$ Torr $\mathrm{O}_{2}$ ) was admitted to the IR cell while the pre-treated samples were held at $200{ }^{\circ} \mathrm{C}$. IR spectra were recorded (also 256 scans) as a function of exposure time. For the second set of stepwise $\left(\mathrm{NO}_{2}+\mathrm{O}_{2}\right)$ adsorption, $\left({ }^{15} \mathrm{NO}+\mathrm{NH}_{3}+\mathrm{O}_{2}\right)$ adsorption and reaction, and TPD experiments, a mixture of $\left(0.15\right.$ Torr $\mathrm{NO}_{2}+1.35$ Torr $\left.\mathrm{O}_{2}\right)$ was first introduced to the IR cell with the samples held at $200{ }^{\circ} \mathrm{C}$. After 36 min of exposure, the IR cell was evacuated for 5 min until the pressure was below $1 \times 10^{-6}$ Torr. A mixture of $\left(0.15\right.$ Torr ${ }^{15} \mathrm{NO}+0.60$ Torr $\mathrm{NH}_{3}+0.75$ Torr $\mathrm{O}_{2}$ ) was subsequently added to the IR cell. After $24 \mathrm{~min}$, the IR cell was evacuated again for 5 min. Finally the samples were heated from 200 to $500{ }^{\circ} \mathrm{C}$ at a ramping rate of $30{ }^{\circ} \mathrm{C} / \mathrm{min}$. FTIR spectra were recorded during the various steps at $200^{\circ} \mathrm{C}$. Mass spectrometer signals of selected masses were continuously recorded during these gas exposure experiments although only the data collected during TPD are reported here. For the third set of experiments, the pre-treated catalysts were exposed to $\left(0.6\right.$ Torr $\mathrm{NH}_{3}+0.9$ Torr $\left.\mathrm{O}_{2}\right)$ for 6 min for $\mathrm{NH}_{3}$ adsorption. The IR cell was then evacuated and a mixture of $\left(0.15\right.$ Torr ${ }^{15} \mathrm{NO}+0.15$ Torr $\mathrm{NO}_{2}+0.3$ Torr $\mathrm{NH}_{3}+0.9$ Torr $\mathrm{O}_{2}$ ) was re-introduced. After 24 min of SCR reaction, the IR cell was evacuated for 5 min. Finally TPD measurements were carried out by heating the samples from 200 to $500{ }^{\circ} \mathrm{C}$ at a ramping rate of $30{ }^{\circ} \mathrm{C} / \mathrm{min}$. Masses of $\mathrm{N}$-containing compounds with $\mathrm{M} / \mathrm{e}=17\left({ }^{14} \mathrm{NH}_{3}\right), 28$ $\left({ }^{14} \mathrm{~N}^{14} \mathrm{~N}\right), 29\left({ }^{15} \mathrm{~N}^{14} \mathrm{~N}\right), 30\left({ }^{14} \mathrm{NO}\right.$ and the fragment of $\left.{ }^{14} \mathrm{NO}_{2}\right), 31\left({ }^{15} \mathrm{NO}\right.$ and the fragment of $\left.{ }^{15} \mathrm{NO}_{2}\right), 44\left({ }^{14} \mathrm{~N}_{2} \mathrm{O}\right), 45\left({ }^{15} \mathrm{~N}^{14} \mathrm{NO}\right)$, and $46\left({ }^{15} \mathrm{~N}_{2} \mathrm{O}\right.$ and $\left.{ }^{14} \mathrm{NO}_{2}\right)$ are simultaneously recorded.

\section{Results}

3.1. Comparison of $\mathrm{N}_{2} \mathrm{O}$ formation on the $\mathrm{Cu}-\mathrm{BEA}$ and $\mathrm{Cu}-\mathrm{CHA}$ catalysts 
Steady state NOx conversions and the corresponding $\mathrm{N}_{2} \mathrm{O}$ formation levels as a function of temperature for $\mathrm{Cu}-\mathrm{BEA}$ and $\mathrm{Cu}-\mathrm{CHA}$ are presented in Fig. 1. Both catalysts show comparable and high NOx conversions in the temperature region from 175 to $500{ }^{\circ} \mathrm{C}$. On both catalysts, NOx conversions increase with temperature from 175 to $250{ }^{\circ} \mathrm{C}$, and reach nearly $100 \%$ NOx reduction efficiencies at temperatures between 250 and $350{ }^{\circ} \mathrm{C}$ before decreasing above $350{ }^{\circ} \mathrm{C}$. The decline in NOx conversions at temperatures above $350{ }^{\circ} \mathrm{C}$ is caused, at least in part, by the parallel unselective $\mathrm{NH}_{3}$ oxidation reactions on the catalysts, which compete with the SCR reactions for $\mathrm{NH}_{3}$ and reduce overall NOx reduction efficiency.

The profiles of the $\mathrm{N}_{2} \mathrm{O}$ level versus temperature for the two catalysts are also similar. In both cases, $\mathrm{N}_{2} \mathrm{O}$ levels first increase with increasing temperature, then decrease and reach their minima at $350{ }^{\circ} \mathrm{C}$. At temperatures above $350{ }^{\circ} \mathrm{C}$, the $\mathrm{N}_{2} \mathrm{O}$ levels gradually increase again with temperature. However, the amount of $\mathrm{N}_{2} \mathrm{O}$ formed on the two catalysts is drastically different. Notably, at any given temperature, the $\mathrm{N}_{2} \mathrm{O}$ yields on $\mathrm{Cu}-\mathrm{BEA}$ are $\sim 3-6$ times higher than on $\mathrm{Cu}$ CHA, in line with prior reports in the literature $[1,18,19]$.

At temperatures above $350{ }^{\circ} \mathrm{C}$, although unselective $\mathrm{NH}_{3}$ oxidation may directly contribute to some of the observed $\mathrm{N}_{2} \mathrm{O}$ production the contribution is likely small. Rather it is more likely that this reaction effectively reduces the $\mathrm{NH}_{3} / \mathrm{NOx}$ ratios to values below the stoichiometric point (1:1) needed for standard SCR, which significantly affects the selectivity of SCR reactions and lead to $\mathrm{N}_{2} \mathrm{O}$ formation. A detailed reaction mechanism for $\mathrm{N}_{2} \mathrm{O}$ formation at temperatures above $350^{\circ} \mathrm{C}$ is, however, beyond the scope of the present study. Instead, we focus here on the origins of $\mathrm{N}_{2} \mathrm{O}$ formation at temperatures $\leq 350{ }^{\circ} \mathrm{C}$, where unselective $\mathrm{NH}_{3}$ oxidation rates are negligible.

\subsection{Effect of $\mathrm{NO}_{2} / \mathrm{NOx}$ ratios on the formation of $\mathrm{N}_{2} \mathrm{O}$}


It is generally accepted that, under low temperature SCR reaction conditions, $\mathrm{N}_{2} \mathrm{O}$ is formed via the decomposition of $\mathrm{NH}_{4} \mathrm{NO}_{3}$, an intermediate formed on the catalyst when ammonia reacts with the surface nitrate groups [6-10, 27-30]. It is also well established that formation of surface nitrates is facilitated with the increase of the $\mathrm{NO}_{2} / \mathrm{NOx}$ ratios in the feed and, correspondingly, $\mathrm{N}_{2} \mathrm{O}$ formation on $\mathrm{Cu} \mathrm{SCR}$ catalysts also increases. Indeed, as can be seen in Fig. 2 where the $\mathrm{N}_{2} \mathrm{O}$ formation rates are plotted as a function of the $\mathrm{NO}_{2} / \mathrm{NOx}$ ratio in the feed gas, such a trend is clearly evident for the large-pore Cu-BEA catalyst at both 200 and 350 ${ }^{\circ} \mathrm{C}$ when the $\mathrm{NO}_{2} / \mathrm{NOx}$ ratio gradually increases from 0 to 0.82 . This trend also holds for the small-pore $\mathrm{Cu}-\mathrm{CHA}$ catalyst at $350{ }^{\circ} \mathrm{C}$, although the absolute $\mathrm{N}_{2} \mathrm{O}$ formation rate at a given $\mathrm{NO}_{2} / \mathrm{NOx}$ ratio is always lower than that observed for $\mathrm{Cu}$-BEA. At $200{ }^{\circ} \mathrm{C}$, however, $\mathrm{N}_{2} \mathrm{O}$ formation on $\mathrm{Cu}-\mathrm{CHA}$ increases only slightly when the $\mathrm{NO}_{2} / \mathrm{NOx}$ ratio increases from 0 to 0.5 . A further increase of the $\mathrm{NO}_{2} / \mathrm{NOx}$ ratio to 0.82 even leads to a decline in $\mathrm{N}_{2} \mathrm{O}$ formation for the catalyst (see Fig. 2).

Of significant interest is an inhibition phenomenon observed for $\mathrm{Cu}-\mathrm{CHA}$ at $200{ }^{\circ} \mathrm{C}$ with an SCR feed containing a $\mathrm{NO}_{2} / \mathrm{NOx}$ ratio of 0.82 . Fig. $3 \mathrm{~A}$ plots outlet concentrations of $\mathrm{NO}$, $\mathrm{NO}_{2}, \mathrm{~N}_{2} \mathrm{O}$ and $\mathrm{NH}_{3}$ during the experiment on Cu-CHA. Starting from a freshly pre-treated sample, both $\mathrm{NO}$ and $\mathrm{NO}_{2}$ concentrations decrease first with reaction time, achieving nearly $65 \%$ instantaneous total NOx conversion at a reaction time of $\sim 10 \mathrm{~min}$. Thereafter, the NO outlet concentration increase monotonically until a reaction time of $\sim 40 \mathrm{~min}$ and levels off thereafter. During this period, the $\mathrm{NO}_{2}$ outlet concentration keeps decreasing. After $\sim 40$ min of reaction, the $\mathrm{NO}_{2}$ outlet concentration increases sharply and approaches a plateau of around $230 \mathrm{ppm} . \mathrm{NH}_{3}$ also starts to break through rapidly after a reaction time of $\sim 50 \mathrm{~min}$. Upon reaching a quasisteady state after a reaction time of $\sim 100$ min, only $\sim 23 \%$ of NOx conversion is achieved for the 
$\mathrm{Cu}-\mathrm{CHA}$ catalyst. Note that under $\mathrm{SCR}$ reaction conditions at $\mathrm{NO}_{2} / \mathrm{NOx}$ ratios below 0.5 , steadystate NOx conversions are always $\geq 98 \%$ at $200{ }^{\circ} \mathrm{C}$ for this catalyst. This clearly indicates that, with an $\mathrm{NO}_{2} / \mathrm{NOx}$ ratio of 0.82 in the feed, a significant quantity of deposits are generated on the small-pore $\mathrm{Cu}-\mathrm{CHA}$ catalyst and inhibit the SCR reaction at $200{ }^{\circ} \mathrm{C}$. In contrast, no noticeable inhibition is observed for the large-pore $\mathrm{Cu}$-BEA catalyst at the same reaction conditions. Indeed, as demonstrated in Fig. 3B, the NOx conversion reach steady state at $\sim 92 \%$ for $\mathrm{Cu}-\mathrm{BEA}$ with an $\mathrm{NO}_{2} / \mathrm{NOx}$ ratio of 0.82 in the feed, which is only a few percent lower than the NOx conversions observed on the catalyst at lower $\mathrm{NO}_{2} / \mathrm{NOx}$ ratios.

TPD experiments were subsequently conducted on the samples to probe the nature of the deposits, formed on the catalysts after SCR reactions at $200{ }^{\circ} \mathrm{C}$ at high $\mathrm{NO}_{2} / \mathrm{NOx}$ ratios $(0.5$ and 0.82). During the experiments, $\mathrm{NO}_{2}$ (with a negligible amount of $\mathrm{NO}$ ), $\mathrm{N}_{2} \mathrm{O}$ and $\mathrm{NH}_{3}$ desorption is observed. Clearly these molecules are products from decomposition of $\mathrm{NH}_{4} \mathrm{NO}_{3}$ deposited on the catalysts through a number of possible pathways [31, 32], such as:

$$
\begin{aligned}
& \mathrm{NH}_{4} \mathrm{NO}_{3} \rightarrow \mathrm{N}_{2} \mathrm{O}+2 \mathrm{H}_{2} \mathrm{O} \\
& 4 \mathrm{NH}_{4} \mathrm{NO}_{3} \rightarrow 3 \mathrm{~N}_{2}+2 \mathrm{NO}_{2}+8 \mathrm{H}_{2} \mathrm{O} \\
& \mathrm{NH}_{4} \mathrm{NO}_{3} \rightarrow \mathrm{NH}_{3}+\mathrm{HNO}_{3} \\
& 4 \mathrm{HNO}_{3} \rightarrow 4 \mathrm{NO}_{2}+2 \mathrm{H}_{2} \mathrm{O}+\mathrm{O}_{2}
\end{aligned}
$$

Since the plug-flow reaction system is only equipped with an FTIR analyzer for gas analysis, we were unable to measure $\mathrm{N}_{2}$ formation in the TPD experiments. Hence we cannot quantify $\mathrm{NH}_{4} \mathrm{NO}_{3}$ deposits on the catalysts or the percentage of the $\mathrm{NH}_{4} \mathrm{NO}_{3}$ deposits that decompose to $\mathrm{N}_{2} \mathrm{O}$ during TPD. However, as a first approximation, it is reasonable that the amount of $\mathrm{N}_{2} \mathrm{O}$ released during TPD is proportional to the amount of $\mathrm{NH}_{4} \mathrm{NO}_{3}$ deposited on the catalysts. 
When the $\mathrm{NO}_{2} / \mathrm{NOx}$ ratios in the feed are below 0.5 during the SCR activity testing, no $\mathrm{N}_{2} \mathrm{O}$ is detected in the subsequent TPD experiments either for $\mathrm{Cu}-\mathrm{BEA}$ or $\mathrm{Cu}-\mathrm{CHA}$ (data not shown). At $\mathrm{NO}_{2} / \mathrm{NOx}$ ratios of 0.5 and 0.82 , the $\mathrm{N}_{2} \mathrm{O}$ desorption profiles are shown in Fig. 4. At an $\mathrm{NO}_{2} / \mathrm{NOx}$ ratio of 0.5 , no $\mathrm{N}_{2} \mathrm{O}$ desorption is observed for the $\mathrm{Cu}$-BEA sample, but small amount of $\mathrm{N}_{2} \mathrm{O}$ desorbs from $\mathrm{Cu}-\mathrm{CHA}$ (maximum concentration $\sim 25 \mathrm{ppm}$, peak temperature $\sim 375{ }^{\circ} \mathrm{C}$ ). At an $\mathrm{NO}_{2} / \mathrm{NOx}$ ratio of 0.82 during SCR activity testing, dramatic increase in $\mathrm{N}_{2} \mathrm{O}$ desorption is found in the subsequent TPD. For the Cu-BEA catalyst, $\mathrm{N}_{2} \mathrm{O}$ starts to desorb from the catalyst at $\sim 290^{\circ} \mathrm{C}$ and reaches its peak concentration of $\sim 65 \mathrm{ppm}$ at $\sim 328^{\circ} \mathrm{C}$; on the other hand for the $\mathrm{Cu}-\mathrm{CHA}$ catalyst, the $\mathrm{N}_{2} \mathrm{O}$ peak is substantially stronger and reaches a peak concentration of $\sim 445 \mathrm{ppm}$, about 6 times higher than that measured for the Cu-BEA catalyst. In combination with the $\mathrm{NOx}$ and $\mathrm{NH}_{3}$ outlet traces shown in Fig. 3A, it can be concluded that the small-pore $\mathrm{CHA}$ structure can stabilize $\mathrm{NH}_{4} \mathrm{NO}_{3}$ at $200{ }^{\circ} \mathrm{C}$ to such an extent that nearly all the CHA pores are blocked, resulting in the severe inhibition effect as shown in Fig. 3A.

The $\mathrm{N}_{2} \mathrm{O}$ desorption temperatures in the TPD experiments can be an indication of the stability of $\mathrm{NH}_{4} \mathrm{NO}_{3}$ on the catalysts. However, for desorption from zeolite materials, the desorption temperatures are affected by the coverage of the adsorbents because they may undergo multiple desorption/re-adsorption steps prior to the final release. Therefore, it is unfair to compare the $\mathrm{N}_{2} \mathrm{O}$ release temperatures for the $\mathrm{Cu}-\mathrm{CHA}$ and $\mathrm{Cu}$-BEA catalysts based on the just-described SCR/TPD experiments where the $\mathrm{NO}_{2} / \mathrm{NOx}$ ratios are at 0.82 because of the very different amounts of $\mathrm{NH}_{4} \mathrm{NO}_{3}$ deposits. Instead, a more reasonable comparison can be made on the $\mathrm{N}_{2} \mathrm{O}$ TPD profiles for the $\mathrm{Cu}-\mathrm{BEA}$ sample after $\mathrm{SCR}$ reaction in a feed with $\mathrm{NO}_{2} / \mathrm{NOx}=0.82$ and that for the $\mathrm{Cu}-\mathrm{CHA}$ sample in a feed with $\mathrm{NO}_{2} / \mathrm{NOx}=0.5$. In these two cases, the amounts of $\mathrm{N}_{2} \mathrm{O}$ released from the catalysts are comparable. As shown in Fig. 4, the $\mathrm{N}_{2} \mathrm{O}$ releases 
temperature for the $\mathrm{Cu}-\mathrm{CHA}$ sample is $\sim 50^{\circ} \mathrm{C}$ higher than that for the $\mathrm{Cu}-\mathrm{BEA}$ sample, which further corroborate the fact that $\mathrm{NH}_{4} \mathrm{NO}_{3}$ is more stable on the small-pore $\mathrm{Cu}-\mathrm{CHA}$ than on the large-pore $\mathrm{Cu}-\mathrm{BEA}$.

\subsection{In situ FTIR spectra following $\left(\mathrm{NO}+\mathrm{O}_{2}\right)$ and $\left(\mathrm{NO}_{2}+\mathrm{O}_{2}\right)$ adsorption}

Formation of $\mathrm{NH}_{4} \mathrm{NO}_{3}$ requires surface nitrates on the catalysts [9]. In situ FTIR is used in this study to elucidate the surface complexes formed during NOx adsorption, and to compare their reactivity towards $\mathrm{NH}_{3}$ on the $\mathrm{Cu}-\mathrm{BEA}$ and $\mathrm{Cu}-\mathrm{CHA}$ catalysts.

Fig. 5 compares the IR spectra of the surface complexes formed on the two catalysts when these are exposed to a mixture of $\left(\mathrm{NO}+\mathrm{O}_{2}\right)$ at $200{ }^{\circ} \mathrm{C}$. On the $\mathrm{Cu}-\mathrm{BEA}$ sample, bands at 1902 and $1812 \mathrm{~cm}^{-1}$ are observed immediately after introduction of $\mathrm{NO}+\mathrm{O}_{2}$. These two bands can be assigned to $\mathrm{N}-\mathrm{O}$ stretching vibrations from $\mathrm{NO}$ adsorbed on $\mathrm{Cu}^{2+}$ and $\mathrm{Cu}^{+}$sites, respectively $[26,33,34]$. The presence of $\mathrm{Cu}^{+}$on the catalyst is due to auto-reduction of $\mathrm{Cu}^{2+}$ during the high temperature vacuum pretreatment [26]. Note that the subsequent re-oxidation step at $200{ }^{\circ} \mathrm{C}$ is not able to fully re-oxidize the sample. During the $\left(\mathrm{NO}+\mathrm{O}_{2}\right)$ adsorption experiment, however, the remaining $\mathrm{Cu}^{+}$is gradually oxidized as evidenced by the disappearance of the band at $1812 \mathrm{~cm}^{-1}$ after 36 min of $\mathrm{NO}+\mathrm{O}_{2}$ exposure. A group of bands are also observed on the sample in the region of $1550-1650 \mathrm{~cm}^{-1}$, with peaks at $1629,1623,1598$ and $1570 \mathrm{~cm}^{-1}$. Bands in this region are typically attributed to surface nitrate and nitrite groups $[7,26,35]$, but based on most recent publications [36-39] these bands are more likely due to surface nitrates with different types of coordination, such as bridging nitrates and bidentate nitrates. It is worth noting that the intensities of the surface nitrates increase monotonically with time and become the dominant bands after 36 min of exposure. 
The IR spectra of the surface NOx adsorption complexes on the $\mathrm{Cu}-\mathrm{CHA}$ sample are noticeably different. The band at $1812 \mathrm{~cm}^{-1}$ attributed to $\mathrm{NO}$ adsorbed on $\mathrm{Cu}^{+}$is not visible on the $\mathrm{Cu}-\mathrm{CHA}$ sample, suggesting $\mathrm{Cu}^{+}$is readily re-oxidized upon $\mathrm{O}_{2}$ pretreatment at $200{ }^{\circ} \mathrm{C}[40$ 42]. The bands in the region of $1550-1650 \mathrm{~cm}^{-1}$ also show some differences; the peaks appear at 1624,1593 , and $1570 \mathrm{~cm}^{-1}$. At any given exposure time, the intensity of this group of bands is always substantially lower than that observed on the $\mathrm{Cu}$-BEA sample. Another significant difference between the two catalysts is that a relatively intense and broad band, centered at 2155 $\mathrm{cm}^{-1}$, and assigned to $\mathrm{NO}^{+}[26]$, is observed on the $\mathrm{Cu}-\mathrm{CHA}$ sample and its intensity barely changes with exposure time. Notably, this $2155 \mathrm{~cm}^{-1}$ band is almost non-existent in the spectrum from the $\mathrm{Cu}$-BEA sample.

The intensity of the IR bands in the $1550-1650 \mathrm{~cm}^{-1}$ region becomes much higher and rapidly reaches saturation on both $\mathrm{Cu}-\mathrm{BEA}$ and $\mathrm{Cu}-\mathrm{CHA}$ when these are exposed to a mixture of $\left(\mathrm{NO}_{2}+\mathrm{O}_{2}\right)$ (see Fig. 6). Compared with the much weaker IR bands in other regions, this clearly indicates that nitrate ad-species dominate on both catalysts with the exposure of $\left(\mathrm{NO}_{2}+\mathrm{O}_{2}\right)$.

The surface nitrate groups on both catalysts are relatively stable in vacuum, showing no decrease in intensity after evacuation at $200^{\circ} \mathrm{C}$ (plotted in Fig. 7 as $\mathrm{Cu}-\mathrm{BEA}(0 \mathrm{~min})$ and $\mathrm{Cu}-$ CHA (0 min), respectively). However, they are very reactive to $\mathrm{NH}_{3}$. As shown in Fig. 7 , the $1629 \mathrm{~cm}^{-1}$ band on $\mathrm{Cu}-\mathrm{BEA}$ and the $1624 \mathrm{~cm}^{-1}$ band on $\mathrm{Cu}-\mathrm{CHA}$ vanish within 1 min when a mixture of $\left({ }^{15} \mathrm{NO}+\mathrm{NH}_{3}+\mathrm{O}_{2}\right)$ is admitted into the IR cell. In the meantime, very broad bands in the region of $1300-1900 \mathrm{~cm}^{-1}$ appear. Because of their broadness, the nature of the surface species corresponding to these bands cannot be readily elucidated. In general, they can be attributed to ammonium nitrates on the catalyst surface [7, 28, 35]. An additional broad IR feature in the region between 1350 and $1550 \mathrm{~cm}^{-1}$ also becomes apparent for the Cu-CHA 
sample. This band has been assigned to $\mathrm{NH}_{3}$ adsorbed on the Brønsted acid sites of the CHA support [43].

These new IR bands are very broad and they overlap with the original nitrate bands on the samples. In order to gain additional insights into the relative reactivity of the original surface nitrate groups, the IR spectra of the $\mathrm{Cu}-\mathrm{BEA}$ or the $\mathrm{Cu}-\mathrm{CHA}$ sample after exposure to the $\left({ }^{15} \mathrm{NO}\right.$ $+\mathrm{NH}_{3}+\mathrm{O}_{2}$ ) mixture for 1 or $3 \mathrm{~min}$, are further subtracted by the IR spectrum of the corresponding sample after exposure to this mixture for $24 \mathrm{~min}$. The plot is inserted in Fig. 7. For the $\mathrm{Cu}-\mathrm{BEA}$ catalyst, it is clear that the IR bands at 1623,1598 and $1570 \mathrm{~cm}^{-1}$ decline slower than the $1629 \mathrm{~cm}^{-1}$ band. It also appears that the intensity decrease of the three lower-frequency bands follows the same trend, indicating that they might be from the same surface complex, but different from the species responsible for the IR band at $1629 \mathrm{~cm}^{-1}$. For the Cu-CHA catalyst, the situation is less obvious, but the $1624 \mathrm{~cm}^{-1}$ band also drops faster than the bands at 1593 and $1570 \mathrm{~cm}^{-1}$, suggesting these are from two different groups of surface complexes. These results seem to support the IR band assignments made by recent publications [36-39] that the two types of surface complexes are from surface nitrates with two different types of coordination.

The newly formed ammonium nitrate species and the adsorbed $\mathrm{NH}_{3}$ on the $\mathrm{Cu}-\mathrm{CHA}$ sample are stable and remain on the catalyst surface with no change in IR signal intensity upon evacuation at $200{ }^{\circ} \mathrm{C}$. The ammonium nitrate on the $\mathrm{Cu}$-BEA sample appears to be less stable, showing a moderate decrease in intensity of their IR features after evacuation. (see Fig. 7).

It should be pointed out that isotope-labeled ${ }^{15} \mathrm{NO}$ has been intentionally used in the second step of the FTIR experiments for several reasons. First, if new surface nitrate groups form on the catalyst surface after $\left({ }^{15} \mathrm{NO}+\mathrm{NH}_{3}+\mathrm{O}_{2}\right)$ introduction to the IR cell, they should contain ${ }^{15} \mathrm{~N}$ and, therefore, their IR bands should appear at lower frequencies and will not overlap with 
the original surface nitrate groups formed during the first $\left(\mathrm{NO}_{2}+\mathrm{O}_{2}\right)$ adsorption step. This enables us to determine that the intensity changes for the original nitrate groups are truly due to their consumption through reactions with $\mathrm{NH}_{3}$ in the second step.

Second, by monitoring the gas phase product of ${ }^{14} \mathrm{~N}^{14} \mathrm{~N}$ during the $\left({ }^{15} \mathrm{NO}+\mathrm{NH}_{3}+\mathrm{O}_{2}\right)$ exposure period, it is possible to elucidate the possible reaction pathways between the original ${ }^{14} \mathrm{~N}$-containing surface complexes and $\mathrm{NH}_{3}$. For both catalysts, the $\mathrm{M} / \mathrm{e}=28\left({ }^{14} \mathrm{~N}^{14} \mathrm{~N}\right)$ signals remain at the baseline level while the M/e $=29\left({ }^{15} \mathrm{~N}^{14} \mathrm{~N}\right)$ signal intensities increase. These results indicate that the reactions between the ${ }^{14} \mathrm{~N}$-containing surface nitrates and $\mathrm{NH}_{3}$ mainly lead to the formation of ammonium nitrate deposits on the catalysts regardless of the type of coordination of the surface nitrate groups. In addition, these results also suggest that there is no appreciable amount of surface nitrites formed on the catalysts during the first $\left(\mathrm{NO}_{2}+\mathrm{O}_{2}\right)$ adsorption step. Surface nitrites are known to be highly reactive with $\mathrm{NH}_{3}$ and decompose to $\mathrm{N}_{2}$ according to the following reaction [30],

$$
\mathrm{HONO}+\mathrm{NH}_{3}=\left[\mathrm{NH}_{4} \mathrm{NO}_{2}\right]=\mathrm{N}_{2}+2 \mathrm{H}_{2} \mathrm{O}
$$

The lack of ${ }^{14} \mathrm{~N}^{14} \mathrm{~N}$ in the $\left({ }^{15} \mathrm{NO}+\mathrm{NH}_{3}+\mathrm{O}_{2}\right)$ reaction step rules out this reaction pathway, indicating negligible amount of surface nitrites on the catalysts.

Finally, and perhaps most importantly, by monitoring the isotope-labeled $\mathrm{N}$ products in the following TPD experiments, it allows us to determine the origins of the nitrate species in the ammonium nitrate deposits formed on the catalysts.

\subsection{TPD under vacuum}

After the in situ FTIR experiments described above, i.e., after the sequence of (1) $\left(\mathrm{NO}_{2}+\right.$ $\left.\mathrm{O}_{2}\right)$ adsorption, (2) evacuation, and (3) $\left({ }^{15} \mathrm{NO}+\mathrm{NH}_{3}+\mathrm{O}_{2}\right)$ exposure and reaction, the IR cell is evacuated again until the pressure drops to below $1 \times 10^{-6}$ Torr. TPD experiments were then 
carried out at a ramping rate of $30^{\circ} \mathrm{C} / \mathrm{min}$. Release of $\mathrm{NH}_{3}$ is observed on the catalysts during the TPD experiments. Because $\mathrm{NH}_{3}$ desorption from the acid sites of the zeolite support and ammonium nitrate decomposition both contribute to the $\mathrm{M} / \mathrm{e}=17$ signal, its relative intensity is much higher than any other masses. The $\mathrm{NH}_{3}$ TPD profiles are not presented here for simplicity. On the other hand, the signals at $\mathrm{M} / \mathrm{e}=44,45$, and 46 remain at their baseline levels, indicating negligible amounts of $\mathrm{N}_{2} \mathrm{O}$ desorption during TPD. This implies that ammonium nitrate decomposition according to reaction (1) is not a major pathway during the TPD experiments under vacuum.

The signals of $M / e=28,29,30$, and 31 are plotted in Fig. 8. A simultaneous increase of the signal intensities of $\mathrm{M} / \mathrm{e}=28$ and 30 upon temperature increase is observed for both catalysts. The M/e $=28$ signal can be attributed to the release of ${ }^{14} \mathrm{~N}_{2}$ from the catalysts. Since no NO was observed in the TPD experiments under flowing conditions (as mentioned in section 3.2.), and it is known that $\mathrm{NO}_{2}$ easily fragment to $\mathrm{NO}$ in a mass spectrometer, it is reasonable to attribute the M/e $=30$ signal to be originated mainly from $\mathrm{NO}_{2}$. Therefore, the simultaneous occurrences of $\mathrm{M} / \mathrm{e}=28$ and 30 signals can be attributed to the release of ${ }^{14} \mathrm{~N}_{2}$ and ${ }^{14} \mathrm{NO}_{2}$ from the catalysts due to the decomposition of $\mathrm{NH}_{4} \mathrm{NO}_{3}$ according to reaction (2). For the $\mathrm{Cu}-\mathrm{BEA}$ sample, the signals at $\mathrm{M} / \mathrm{e}=28$ and 30 maximize at $\sim 300-325^{\circ} \mathrm{C}$, suggesting ammonium nitrate decomposition is essentially complete around these temperatures. At higher temperatures, the signals level off due to $\mathrm{NH}_{4} \mathrm{NO}_{3}$ depletion. For the $\mathrm{Cu}-\mathrm{CHA}$ sample on the other hand, the increase in intensities for $\mathrm{M} / \mathrm{e}=28$ and 30 is slightly slower than that for the $\mathrm{Cu}-\mathrm{BEA}$ sample at temperatures below $300{ }^{\circ} \mathrm{C}$, but significantly greater at temperatures above $300{ }^{\circ} \mathrm{C}$. In fact, both of these M/e signals grow continuously during the TPD experiment, demonstrating substantially more $\mathrm{NH}_{4} \mathrm{NO}_{3}$ deposition on the $\mathrm{Cu}-\mathrm{CHA}$ sample. 
It is very interesting to notice that the signals at $\mathrm{M} / \mathrm{e}=29\left({ }^{14} \mathrm{~N}^{15} \mathrm{~N}\right)$ and 31 (fragment of ${ }^{15} \mathrm{NO}_{2}$ ) in Fig. 8 remain at their baseline levels during TPD. This indicates that there are essentially no $\mathrm{NH}_{4}{ }^{15} \mathrm{NO}_{3}$ deposits formed on either of the catalysts during the exposure of $\left({ }^{15} \mathrm{NO}\right.$ $+\mathrm{NH}_{3}+\mathrm{O}_{2}$ ). Therefore, it seems that all of the ammonium nitrate deposits formed on the catalysts are from the ${ }^{14} \mathrm{~N}$-containing surface nitrate groups deposited on the catalysts during the first $\left(\mathrm{NO}_{2}+\mathrm{O}_{2}\right)$ adsorption step.

To further probe the reaction pathways for ammonium nitrate formation on the $\mathrm{Cu}$-BEA and $\mathrm{Cu}-\mathrm{CHA}$ catalysts under SCR reaction conditions, another set of experiments were carried out by admitting a mixture of $\left({ }^{15} \mathrm{NO}+\mathrm{NO}_{2}+\mathrm{NH}_{3}+\mathrm{O}_{2}\right)$ to the catalysts that were pre-dosed with $\mathrm{NH}_{3}$. The mole ratio of ${ }^{15} \mathrm{NO} / \mathrm{NO}_{2}$ is adjusted to $1: 1$ for these experiments, and the mixture was introduced into the IR cell immediately after mixing ${ }^{15} \mathrm{NO}$ and $\mathrm{NO}_{2}$ to minimize isotope scrambling from homogeneous gas phase reactions. After 24 min of exposure and a subsequent evacuation step at $200{ }^{\circ} \mathrm{C}$, TPD experiments were conducted on both catalysts. The TPD profiles for the $\mathrm{M} / \mathrm{e}=28,29,30$, and 31 signals for both catalysts are plotted in Fig. 9.

For the $\mathrm{Cu}-\mathrm{BEA}$ sample, all signals remain close to their baseline levels except weak M/e $=28$ signals from $\sim 250$ to $300{ }^{\circ} \mathrm{C}$. This suggests that there is only trace amount of nitrate deposition on this catalyst, likely from $\mathrm{NO}_{2}$ in the feed. In contrast, relatively large quantities of $\mathrm{N}_{2}(\mathrm{M} / \mathrm{e}=28)$ and $\mathrm{NO}_{2}(\mathrm{M} / \mathrm{e}=30)$ are released from the $\mathrm{Cu}-\mathrm{CHA}$ sample, yet again, no ${ }^{15} \mathrm{~N}^{14} \mathrm{~N}$ $(\mathrm{M} / \mathrm{e}=29)$ or ${ }^{15} \mathrm{NO}_{2}(\mathrm{M} / \mathrm{e}=31)$ desorption is observed. This unambiguously demonstrates that ammonium nitrate is more stable on the $\mathrm{Cu}-\mathrm{CHA}$ catalyst, and that only $\mathrm{NO}_{2}$, but not ${ }^{15} \mathrm{NO}$, contributes to its formation.

\section{Discussion}


Reaction data in Fig. 1 demonstrate that, under the SCR reaction conditions where the two catalysts exhibit comparable overall NOx reduction efficiencies, $\mathrm{N}_{2} \mathrm{O}$ formation on the small-pore $\mathrm{Cu}-\mathrm{CHA}$ catalyst is noticeably lower than that on the large-pore $\mathrm{Cu}$-BEA catalyst. The results are consistent with what has been reported in the literature $[1,18,19]$, hence allowing us to use these two catalysts to address the fundamental question of why small-pore zeolite supported $\mathrm{Cu}$ SCR catalysts are, in general, more selective to $\mathrm{N}_{2}$ with less $\mathrm{N}_{2} \mathrm{O}$ formation. As has been proposed in the literature that low-temperature $\mathrm{N}_{2} \mathrm{O}$ formation is via the decomposition of SCR intermediate $\mathrm{NH}_{4} \mathrm{NO}_{3}$ [6-10, 28-30], we first discuss the possible correlation between $\mathrm{N}_{2} \mathrm{O}$ yield and the tendency of $\mathrm{NH}_{4} \mathrm{NO}_{3}$ formation on the $\mathrm{Cu}-\mathrm{BEA}$ and $\mathrm{Cu}-$ CHA catalysts.

$\mathrm{NH}_{4} \mathrm{NO}_{3}$ formation involves surface nitrate groups [9]. One way to promote the formation of surface nitrate groups is to increase the $\mathrm{NO}_{2} / \mathrm{NOx}$ ratio of the reactant feed. Surface nitrate groups are readily generated via $\mathrm{NO}_{2}$ disproportionation [30]:

$$
2 \mathrm{NO}_{2}=\mathrm{NO}^{+}+\mathrm{NO}_{3}^{-}
$$

Therefore, higher $\mathrm{NO}_{2} / \mathrm{NOx}$ ratios in the feed favor surface nitrate formation. At $350{ }^{\circ} \mathrm{C}$, a temperature high enough that $\mathrm{NH}_{4} \mathrm{NO}_{3}$ decomposes immediately upon formation, the $\mathrm{N}_{2} \mathrm{O}$ yields on both catalysts increase monotonically with an increase in the $\mathrm{NO}_{2} / \mathrm{NOx}$ ratios (Fig. 2). The results are fully consistent with the generally accepted conclusion that $\mathrm{N}_{2} \mathrm{O}$ formation is through $\mathrm{NH}_{4} \mathrm{NO}_{3}$ decomposition.

$\mathrm{N}_{2} \mathrm{O}$ formation on the $\mathrm{Cu}-\mathrm{BEA}$ catalyst at $200{ }^{\circ} \mathrm{C}$ follows a similar trend with respect to $\mathrm{NO}_{2} / \mathrm{NOx}$ ratios. This correlation is, however, no longer evident for the $\mathrm{Cu}-\mathrm{CHA}$ catalyst at this low temperature. Subsequent TPD experiments (Fig. 4) reveal that this is because $\mathrm{NH}_{4} \mathrm{NO}_{3}$ is more stable for the $\mathrm{Cu}-\mathrm{CHA}$ catalyst and it does not readily decompose at $200{ }^{\circ} \mathrm{C}$. In fact, a self- 
inhibition phenomenon caused by the $\mathrm{NH}_{4} \mathrm{NO}_{3}$ deposits for the $\mathrm{Cu}-\mathrm{CHA}$ catalyst is observed at this temperature when the $\mathrm{NO}_{2} / \mathrm{NOx}$ ratio in the feed gas is at 0.82 (Fig. 3).

$\mathrm{NH}_{4} \mathrm{NO}_{3}$ has long been proposed to be involved in SCR according to the following reactions [30]:

$$
\begin{aligned}
& \mathrm{NH}_{4} \mathrm{NO}_{3}+\mathrm{NO}=\mathrm{NH}_{4} \mathrm{NO}_{2}+\mathrm{NO}_{2} \\
& \mathrm{NH}_{4} \mathrm{NO}_{2}=\mathrm{N}_{2}+2 \mathrm{H}_{2} \mathrm{O}
\end{aligned}
$$

As our results substantiate, $\mathrm{NH}_{4} \mathrm{NO}_{3}$ is more stable on the small-pore $\mathrm{Cu}-\mathrm{CHA}$ catalyst, it is reasonable to assume that it has higher probabilities to react with NO (especially under SCR reaction conditions with a feed of $\mathrm{NO}_{2} / \mathrm{NOx}$ ratio less than 0.5 ) and subsequently decomposes to $\mathrm{N}_{2}$ via a nitrite intermediate. Note that reactions (7) and (8) compete with the decomposition pathway (1); this provides a reasonable explanation on the lower $\mathrm{N}_{2} \mathrm{O}$ formation over $\mathrm{Cu}-\mathrm{CHA}$.

Although the results of this study cannot explain the fundamentals of the higher thermal stabilities for $\mathrm{NH}_{4} \mathrm{NO}_{3}$ in the small-pore $\mathrm{Cu}-\mathrm{CHA}$ catalyst, it is speculated that the pore restriction plays a major role in the stabilization of $\mathrm{NH}_{4} \mathrm{NO}_{3}$. It is plausible that the small dimension of the openings in the $\mathrm{CHA}$ framework confines $\mathrm{NH}_{4} \mathrm{NO}_{3}$ in the CHA cages and makes it more stable. The general trend that $\mathrm{N}_{2} \mathrm{O}$ yields on zeolite supported $\mathrm{Cu}$ SCR catalysts decrease following the order of small-pore $<$ medium-pore $<$ large-pore zeolite structures seems to support this hypothesis: the smaller the pores of the zeolite support, the higher the stability of $\mathrm{NH}_{4} \mathrm{NO}_{3}$ in the zeolite cages, hence the lower $\mathrm{N}_{2} \mathrm{O}$ yields on the catalysts under SCR reaction conditions.

Since surface nitrate groups are crucial for the formation of $\mathrm{NH}_{4} \mathrm{NO}_{3}$, we also have to consider and compare the activity of the two catalysts in the formation of these surface complexes. The FTIR results presented in Fig. 5 indicate that the intensity of the IR bands 
corresponding to the nitrate groups on the $\mathrm{Cu}-\mathrm{CHA}$ catalyst is noticeably weaker than that on the $\mathrm{Cu}$-BEA catalyst after exposure to the same $\left(\mathrm{NO}+\mathrm{O}_{2}\right)$ mixture. However, this does not necessarily indicate that $\mathrm{Cu}-\mathrm{CHA}$ is less active in catalyzing $\mathrm{NO}$ oxidation and the subsequent formation of surface nitrate groups. This is because the exact nature of the surface nitrate groups deposited on the two catalysts is still not fully understood. For example, some of the IR bands do not appear at the same frequencies on the two samples. However, since the saturation signal intensities for the nitrate groups on both catalysts are readily achieved upon exposure to a $\left(\mathrm{NO}_{2}+\right.$ $\mathrm{O}_{2}$ ) mixture (Fig. 6), these saturation intensities can be used to normalize the intensities of the corresponding sample in the $\left(\mathrm{NO}+\mathrm{O}_{2}\right)$ experiments. Accordingly, Fig. 10 plots the normalized intensities for the IR band at $1629 \mathrm{~cm}^{-1}$ (for Cu-BEA) and $1624 \mathrm{~cm}^{-1}$ (for $\mathrm{Cu}-\mathrm{CHA}$ ) as a function of exposure time in the $\left(\mathrm{NO}+\mathrm{O}_{2}\right)$ experiments. By comparing the normalized signal intensities in Fig. 10, we can conclude that the $\mathrm{Cu}-\mathrm{CHA}$ catalyst is indeed less active than the Cu-BEA catalyst in catalyzing $\mathrm{NO}$ oxidation and the subsequent formation of surface nitrate groups.

The nitrate groups on both catalysts are thermally stable at $200{ }^{\circ} \mathrm{C}$, but are reactive toward $\mathrm{NH}_{3}$ (under the atmosphere of $\left.\left({ }^{15} \mathrm{NO}+\mathrm{NH}_{3}+\mathrm{O}_{2}\right)\right)$ as demonstrated by the FTIR spectra in Fig. 7. Based on the rate of their disappearance, the surface nitrate complexes can be further divided into two sub-groups: on the $\mathrm{Cu}$-BEA sample, the group giving rise to the $1629 \mathrm{~cm}^{-1}$ band is more reactive than the group with IR bands at 1623,1598 , and $1570 \mathrm{~cm}^{-1}$; on the $\mathrm{Cu}-\mathrm{CHA}$ sample, the situation is less obvious because of more severe band overlapping, but the same trend is also envisioned. Based on assignments by Ruggeri et al. [36], the IR band at $1629 \mathrm{~cm}^{-1}$ for the $\mathrm{Cu}$-BEA sample and of that at $1624 \mathrm{~cm}^{-1}$ for the $\mathrm{Cu}-\mathrm{CHA}$ sample can be assigned to surface bridging nitrate species while the rest of the IR bands in the $1500-1700 \mathrm{~cm}^{-1}$ region (at 1623, 1598, and $1570 \mathrm{~cm}^{-1}$ on the Cu-BEA sample, and at 1593 and $1570 \mathrm{~cm}^{-1}$ on the Cu-CHA 
sample) are attributed to surface bidentate nitrate moieties. On both catalysts, although the bridging nitrate species appear to be more reactive, both the bridging nitrates and the bidentate nitrates react with $\mathrm{NH}_{3}$ forming $\mathrm{NH}_{4} \mathrm{NO}_{3}$ deposits. Consistent with the strong $\mathrm{NH}_{4} \mathrm{NO}_{3}$ inhibition effect only observed on $\mathrm{Cu}-\mathrm{CHA}$ at $200{ }^{\circ} \mathrm{C}$ (Fig. 3), much stronger signal in the $\mathrm{NH}_{4} \mathrm{NO}_{3}$ vibrational region (1300-1500 $\mathrm{cm}^{-1}$ ) is observed on $\mathrm{Cu}-\mathrm{CHA}$ following $\mathrm{NH}_{3}$ and surface nitrate interactions (Fig. 7).

In the subsequent TPD experiment, it is evident based on the product distribution shown in Fig. 8 that the ammonium nitrate deposits left on either of the catalysts are all in the form of $\mathrm{NH}_{4} \mathrm{NO}_{3}$ with a negligible contribution from $\mathrm{NH}_{4}{ }^{15} \mathrm{NO}_{3}$. Since isotope-labelled ${ }^{15} \mathrm{NO}$ is used in the second $\left({ }^{15} \mathrm{NO}+\mathrm{NH}_{3}+\mathrm{O}_{2}\right)$ adsorption/reaction step, the only reaction pathway leading to the $\mathrm{NH}_{4} \mathrm{NO}_{3}$ deposit formation is the reaction of $\mathrm{NH}_{3}$ with the ${ }^{14} \mathrm{~N}$-containing surface nitrate groups already formed on the catalyst during the first $\left(\mathrm{NO}_{2}+\mathrm{O}_{2}\right)$ adsorption step. From the signal intensities, it is also evident that the amount of $\mathrm{NH}_{4} \mathrm{NO}_{3}$ deposits on the $\mathrm{Cu}-\mathrm{BEA}$ sample is much less than that on the $\mathrm{Cu}-\mathrm{CHA}$ sample. This indicates that a portion of the $\mathrm{NH}_{4} \mathrm{NO}_{3}$, formed on the $\mathrm{Cu}$-BEA catalyst from the original surface nitrates, decompose or undergo SCR reactions during the $\left({ }^{15} \mathrm{NO}+\mathrm{NH}_{3}+\mathrm{O}_{2}\right)$ adsorption/reaction step. The already facile ammonium nitrate decomposition reaction on the $\mathrm{Cu}-\mathrm{BEA}$ catalyst at $200{ }^{\circ} \mathrm{C}$ makes it difficult to argue whether the absence of $\mathrm{NH}_{4}{ }^{15} \mathrm{NO}_{3}$ deposits on the Cu-BEA catalyst is due to the lack of its formation, or because its decomposition/reaction is rapid enough, therefore, it cannot accumulate on the catalyst. The situation, however, is much more straight-forward for the $\mathrm{Cu}-\mathrm{CHA}$ catalyst. The results from Fig. 8 and Fig. 4 clearly demonstrate that ammonium nitrate is stable on this catalyst at $200{ }^{\circ} \mathrm{C}$. Were there an appreciable amount of $\mathrm{NH}_{4}{ }^{15} \mathrm{NO}_{3}$ formed on the catalyst during the $\left({ }^{15} \mathrm{NO}+\mathrm{NH}_{3}+\mathrm{O}_{2}\right)$ adsorption/reaction step, the majority of the $\mathrm{NH}_{4}{ }^{15} \mathrm{NO}_{3}$ would have remained 
on the catalyst and ${ }^{15} \mathrm{~N}$-based compounds would have been detected in the subsequent TPD experiment. Cleary this is not the case as displayed in Fig. $8-$ no ${ }^{15} \mathrm{~N}$-containing species are observed in the post-reaction TPD experiment. This implies that, under SCR reaction conditions with $\mathrm{NO}+\mathrm{O}_{2}$ in the feed, the $\mathrm{Cu}-\mathrm{CHA}$ catalyst is unable to oxidize and convert $\mathrm{NO}$ to surface nitrates, at least at $200{ }^{\circ} \mathrm{C}$.

The results in Fig. 9 further support the conclusions described above. In the TPD experiments after exposing the catalysts to a mixture of $\left({ }^{15} \mathrm{NO}+\mathrm{NO}_{2}+\mathrm{NH}_{3}+\mathrm{O}_{2}\right)$ with the ${ }^{15} \mathrm{NO} / \mathrm{NO}_{2}$ molar ratio of $1 / 1$, only ${ }^{14} \mathrm{~N}$-containing products are detected to desorb from the $\mathrm{Cu}$ CHA sample. This proves that the $\mathrm{Cu}-\mathrm{CHA}$ catalyst does not convert ${ }^{15} \mathrm{NO}$ to surface nitrates. Surface nitrates (which react rapidly with $\mathrm{NH}_{3}$ to form ammonium nitrate deposits) are formed on the $\mathrm{Cu}-\mathrm{CHA}$ catalyst only when sufficient $\mathrm{NO}_{2}$ is present in the gas phase. The reaction pathway that leads to nitrate formation is likely $\mathrm{NO}_{2}$ disproportionation, as illustrated in reaction (6). The lack of any deposits on the Cu-BEA catalyst following the same adsorption and TPD steps (Fig. 9) confirms that ammonium nitrate is not stable on this catalyst under the SCR reaction conditions; it decomposes immediately upon formation.

The results in this study reveal two major differences between the small-pore $\mathrm{Cu}-\mathrm{CHA}$ and the large-pore $\mathrm{Cu}-\mathrm{BEA}$ catalysts: (1) $\mathrm{NH}_{4} \mathrm{NO}_{3}$ is thermally more stable on $\mathrm{Cu}-\mathrm{CHA}$ than on $\mathrm{Cu}-\mathrm{BEA}$; (2) The Cu-CHA catalyst is less active in catalyzing NO oxidation and the subsequent formation of surface nitrate groups. Although both factors may account for the lower $\mathrm{N}_{2} \mathrm{O}$ formation for the $\mathrm{Cu}-\mathrm{CHA}$ catalyst during $\mathrm{SCR}$, the second factor appears to be more important as it reduces the formation of $\mathrm{NH}_{4} \mathrm{NO}_{3}$, the primary source for $\mathrm{N}_{2} \mathrm{O}$ formation at relatively low SCR reaction temperatures. 


\section{Conclusions}

This comparison study has demonstrated much less $\mathrm{N}_{2} \mathrm{O}$ formation on a small-pore $\mathrm{Cu}$ CHA catalyst than a large-pore $\mathrm{Cu}$-BEA catalyst under SCR reaction conditions where the two catalysts exhibit comparable overall NOx reduction efficiencies. $\mathrm{N}_{2} \mathrm{O}$ is formed via the decomposition of $\mathrm{NH}_{4} \mathrm{NO}_{3}$, an intermediate that is formed on the catalysts when $\mathrm{NH}_{3}$ reacts with surface nitrate groups. $\mathrm{NH}_{4} \mathrm{NO}_{3}$ is more stable on the small-pore $\mathrm{Cu}$-CHA catalyst. It is likely that the smaller pore openings of the CHA structure (or other small-pore zeolite structures in general) add additional confinement to $\mathrm{NH}_{4} \mathrm{NO}_{3}$ in the zeolite cages, thus enhancing its thermal stability. Although the higher stability of $\mathrm{NH}_{4} \mathrm{NO}_{3}$ can contribute to the decrease in $\mathrm{N}_{2} \mathrm{O}$ formation on the $\mathrm{Cu}-\mathrm{CHA}$ catalyst, the primary reason is that $\mathrm{Cu}-\mathrm{CHA}$ is less active than $\mathrm{Cu}-$ BEA in catalyzing NO oxidation and the subsequent formation of surface nitrate groups. This results in less $\mathrm{NH}_{4} \mathrm{NO}_{3}$ formation on $\mathrm{Cu}-\mathrm{CHA}$ during standard $\mathrm{SCR}$ reaction, thus eliminating its decomposition to $\mathrm{N}_{2} \mathrm{O}$.

\section{Acknowledgments}

HYC is grateful to Johnson Matthey for the support of this collaboration work and to PNNL for an Alternate Sponsored Fellowship. The authors at PNNL gratefully acknowledge the US Department of Energy (DOE), Energy Efficiency and Renewable Energy, Vehicle Technologies Office for the support of this work. The research described in this paper was performed at the Environmental Molecular Sciences Laboratory (EMSL), a national scientific user facility sponsored by the DOE's Office of Biological and Environmental Research and located at Pacific Northwest National Laboratory (PNNL). PNNL is operated for the US DOE by Battelle. 


\section{References}

[1] H.-Y. Chen, Cu/Zeolite SCR Catalysts for Automotive Diesel NOx Emission Control, in: I.

Nova, E. Tronconi (Eds.) Urea-SCR Technology for deNOx After Treatment of Diesel Exhausts, Springer New York, 2014, pp. 123-147.

[2] F. Gao, J. Kwak, J. Szanyi, C.F. Peden, Top Catal, 56 (2013) 1441-1459.

[3] G. Centi, S. Perathoner, Applied Catalysis A: General, 132 (1995) 179-259.

[4] S. Brandenberger, O. Kröcher, A. Tissler, R. Althoff, Catalysis Reviews, 50 (2008) 492-531.

[5] T. Seiyama, T. Arakawa, T. Matsuda, Y. Takita, N. Yamazoe, Journal of Catalysis, 48 (1977)

$1-7$.

[6] J.G.M. Brandin, L.A.H. Andersson, C.U.I. Odenbrand, Catalysis Today, 4 (1989) 187-203.

[7] J.M. Fedeyko, B. Chen, H.-Y. Chen, Catalysis Today, 151 (2010) 231-236.

[8] O. Mihai, C.R. Widyastuti, S. Andonova, K. Kamasamudram, J. Li, S.Y. Joshi, N.W. Currier, A. Yezerets, L. Olsson, Journal of Catalysis, 311(2014) 170-181.

[9] G. Delahay, B. Coq, S. Kieger, B. Neveu, Catalysis Today, 54 (1999) 431-438.

[10] L.A.H. Andersson, J.G.M. Brandin, C.U.I. Odenbrand, Catalysis Today, 4 (1989) 173-185.

[11] K. Rahkamaa-Tolonen, T. Maunula, M. Lomma, M. Huuhtanen, R.L. Keiski, Catalysis Today, 100 (2005) 217-222.

[12] H. Yahiro, M. Iwamoto, Applied Catalysis A: General, 222 (2001) 163-181.

[13] T. Komatsu, M. Nunokawa, I.S. Moon, T. Takahara, S. Namba, T. Yashima, Journal of Catalysis, 148 (1994) 427-437.

[14] Q. Ye, L. Wang, R.T. Yang, Applied Catalysis A: General, 427-428 (2012) 24-34.

[15] D.W. Fickel, E. D’Addio, J.A. Lauterbach, R.F. Lobo, Applied Catalysis B: Environmental, 102 (2011) 441-448. 
[16] D.W. Fickel, R.F. Lobo, The Journal of Physical Chemistry C, 114 (2009) 1633-1640.

[17] M. Moliner, C. Franch, E. Palomares, M. Grill, A. Corma, Chemical Communications, 48 (2012) 8264-8266.

[18] J.H. Kwak, D. Tran, S.D. Burton, J. Szanyi, J.H. Lee, C.H.F. Peden, Journal of Catalysis, 287 (2012) 203-209.

[19] J.H. Kwak, R.G. Tonkyn, D.H. Kim, J. Szanyi, C.H.F. Peden, Journal of Catalysis, 275 (2010) 187-190.

[20] P.G. Blakeman, E.M. Burkholder, H.-Y. Chen, J.E. Collier, J.M. Fedeyko, H. Jobson, R.R. Rajaram, Catalysis Today, 231 (2014) 56-63.

[21] Q.L. Wang, G. Giannetto, M. Torrealba, G. Perot, C. Kappenstein, M. Guisnet, Journal of Catalysis, 130 (1991) 459-470.

[22] T. Sano, H. Ikeya, T. Kasuno, Z.B. Wang, Y. Kawakami, K. Soga, Zeolites, 19 (1997) 8086.

[23] N. Wilken, K. Wijayanti, K. Kamasamudram, N.W. Currier, R. Vedaiyan, A. Yezerets, L. Olsson, Applied Catalysis B: Environmental, 111-112 (2012) 58-66.

[24] A.V. Kucherov, C.P. Hubbard, M. Shelef, Journal of Catalysis, 157 (1995) 603-610.

[25] R.A. Grinsted, H.W. Jen, C.N. Montreuil, M.J. Rokosz, M. Shelef, Zeolites, 13 (1993) 602606.

[26] J. Szanyi, J.H. Kwak, H. Zhu, C.H.F. Peden, Physical Chemistry Chemical Physics, 15 (2013) 2368-2380.

[27] M. Colombo, I. Nova, E. Tronconi, Catalysis Today, 197 (2012) 243-255.

[28] L. Xie, F. Liu, K. Liu, X. Shi, H. He, Catalysis Science \& Technology, 4 (2014) 1104-1110. 
[29] S. Suárez, J.A. Martín, M. Yates, P. Avila, J. Blanco, Journal of Catalysis, 229 (2005) 227 236.

[30] Y.H. Yeom, J. Henao, M.J. Li, W.M.H. Sachtler, E. Weitz, Journal of Catalysis, 231 (2005) 181-193.

[31] M.S. Shah, T.M. Oza, Journal of the Chemical Society (Resumed), (1932) 725-736.

[32] K.R. Brower, J.C. Oxley, M. Tewari, The Journal of Physical Chemistry, 93 (1989) 40294033.

[33] F. Giordanino, P.N.R. Vennestrom, L.F. Lundegaard, F.N. Stappen, S. Mossin, P. Beato, S. Bordiga, C. Lamberti, Dalton Transactions, 42 (2013) 12741-12761.

[34] K.I. Hadjiivanov, Catalysis Reviews, 42 (2000) 71-144.

[35] H. Zhu, J.H. Kwak, C.H.F. Peden, J. Szanyi, Catalysis Today, 205 (2013) 16-23.

[36] M.P. Ruggeri, I. Nova, E. Tronconi, J.A. Pihl, T.J. Toops, W.P. Partridge, Applied Catalysis

B: Environmental, 166-167 (2015) 181-192.

[37] L. Ma, Y, Cheng, G. Cavataio, R.W. McCabe, L. Fu, J. Li, Applied Catalysis B:

Environmental, 156-157 (2014) 428-437.

[38] T.V.W. Janssens, H. Falsig, L.F. Lundegaard, P.N.R. Vennesterøm. S.B. Rasmussen, P.G. Moses, F. Giordanino, E. Borfecchia, K.A. Lomachenko, C. Lamberti, S. Bordiga, A. Godiksen, S. Mossin, P. Beato, ACS Catalysis, 5 (2015) 2832-2845.

[39] W. Su, H. Chang, Y. Peng, C. Zhang, J. Li, Environmental Science and Technology, 49 (2015) 467-473.

[40] S.A. Bates, A.A. Verma, C. Paulucci, A.A. Parekh, T. Anggara, A. Yezerets, W.F. Schneider, J.T. Miller, W.N. Delgass, F.H. Ribeiro, Journal of Catalysis, 32 (2014) 87-97. 
[41] C. Paulucci, A.A. Verma, S.A. Bates, V.F. Kispersky, J.T. Miller, R. Gounder, W.N.

Delgass, F.H. Ribeiro, W.F. Schneider, Angewandte Communications, 53 (2014) 11828-11833.

[42] E. Borfecchia, K.A. Lomachenko, F. Giordanino, H. Falsig, P. Beato, A.V. Soldatov, S.

Bordiga, C. Lamberti, Chemical Science, 6 (2015) 548-563.

[43] F. Giordanino, E. Borfecchia, K.A. Lomachenko, A. Lazzarini, G. Agostini, E. Gallo, A.V.

Soldatov, P. Beato, S. Bordiga, C. Lamberti, The Journal of Physical Chemistry Letters, 5 (2014)

$1552-1559$. 


\section{Figure captions}

Fig. 1. Steady state NOx conversions and the corresponding $\mathrm{N}_{2} \mathrm{O}$ formation levels as a function of temperature for $\mathrm{Cu}-\mathrm{BEA}$ and $\mathrm{Cu}-\mathrm{CHA}$.

(SCR reaction conditions: $350 \mathrm{ppm} \mathrm{NO}, 350 \mathrm{ppm} \mathrm{NH}_{3}, 10 \% \mathrm{O}_{2}, 2.5 \% \mathrm{H}_{2} \mathrm{O}$, and balance $\mathrm{N}_{2}$, GHSV $=200,000 \mathrm{~h}^{-1}$ )

Fig. 2. Effect of $\mathrm{NO}_{2} / \mathrm{NOx}$ ratios in the feed gas on the $\mathrm{N}_{2} \mathrm{O}$ formation rates for $\mathrm{Cu}-\mathrm{BEA}$ and $\mathrm{Cu}$ CHA.

(Reaction conditions: 350 ppm NOx, 350 ppm $\mathrm{NH}_{3}, 10 \% \mathrm{O}_{2}, 2.5 \% \mathrm{H}_{2} \mathrm{O}$, and balance $\mathrm{N}_{2}$, GHSV $=200,000 \mathrm{~h}^{-1}$ )

Fig. 3. Outlet concentrations of $\mathrm{NO}, \mathrm{NO}_{2}, \mathrm{~N}_{2} \mathrm{O}$, and $\mathrm{NH}_{3}$ downstream of (A) Cu-CHA and (B) Cu-BEA.

(Reaction conditions: 350 ppm NOx (at an $\mathrm{NO}_{2} / \mathrm{NOx}=0.82$ ), $350 \mathrm{ppm} \mathrm{NH}_{3}, 10 \% \mathrm{O}_{2}, 2.5 \%$ $\mathrm{H}_{2} \mathrm{O}$, and balance $\mathrm{N}_{2}, \mathrm{GHSV}=200,000 \mathrm{~h}^{-1}$, temperature $=200{ }^{\circ} \mathrm{C}$ )

Fig. 4. $\mathrm{N}_{2} \mathrm{O}$ TPD of samples after SCR reaction at $200{ }^{\circ} \mathrm{C}$

(TPD was carried out in $10 \% \mathrm{O}_{2}, 2.5 \% \mathrm{H}_{2} \mathrm{O}$, and balance $\mathrm{N}_{2}$, at a GHSV $=200,000 \mathrm{~h}^{-1}$, with a ramping rate of $25{ }^{\circ} \mathrm{C} / \mathrm{min}$; SCR reaction was performed in a feed of $350 \mathrm{ppm}$ NOx (at an

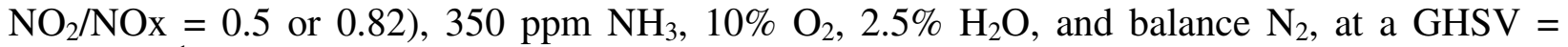
$200,000 \mathrm{~h}^{-1}$ )

Fig. 5. In situ FTIR spectra at $200{ }^{\circ} \mathrm{C}$ of samples upon exposure to $(0.15$ Torr $\mathrm{NO}+1.35$ Torr $\mathrm{O}_{2}$ )

Fig. 6. In situ FTIR spectra at $200{ }^{\circ} \mathrm{C}$ of samples upon exposure to $\left(0.15\right.$ Torr $\mathrm{NO}_{2}+1.35$ Torr $\left.\mathrm{O}_{2}\right)$

Fig. 7. In situ FTIR spectra at $200{ }^{\circ} \mathrm{C}$ of samples after nitrate pre-adsorption (labeled as $(0 \mathrm{~min})$ ); and upon subsequent exposure to $\left(0.15\right.$ Torr ${ }^{15} \mathrm{NO}+0.6$ Torr $\mathrm{NH}_{3}+0.75$ Torr $\left.\mathrm{O}_{2}\right)$ for 1,3 , and $24 \mathrm{~min}$; and finally after evacuation (labeled as (Vacuum)). The $(1 \mathrm{~min})$ and the $(3 \mathrm{~min})$ spectra in the inset plot were further subtracted by the corresponding spectrum after 24 min exposure.

Fig. 8. Mass spectrometer signals in the TPD experiments after the samples were exposed to $\left(0.15\right.$ Torr $\mathrm{NO}_{2}+1.35$ Torr $\left.\mathrm{O}_{2}\right)$ followed by $\left(0.15\right.$ Torr ${ }^{15} \mathrm{NO}+0.6$ Torr $\mathrm{NH}_{3}+0.75$ Torr $\left.\mathrm{O}_{2}\right)$, both at $200^{\circ} \mathrm{C}$

Fig. 9. Mass spectrometer signals in the TPD experiments after the samples were exposed to $\left(0.15\right.$ Torr $\mathrm{NO}_{2}+0.15$ Torr ${ }^{15} \mathrm{NO}+0.3$ Torr $\mathrm{NH}_{3}+0.9$ Torr $\left.\mathrm{O}_{2}\right)$ at $200{ }^{\circ} \mathrm{C}$

Fig. 10. Normalized intensities of IR bands at $1629 \mathrm{~cm}^{-1}$ (for $\mathrm{Cu}-\mathrm{BEA}$ ) and $1624 \mathrm{~cm}^{-1}$ (for $\mathrm{Cu}$ $\mathrm{CHA})$ as a function of exposure time in the $\left(0.15\right.$ Torr $\mathrm{NO}+1.35$ Torr $\left.\mathrm{O}_{2}\right)$ experiments of Fig. 5. 
Figures

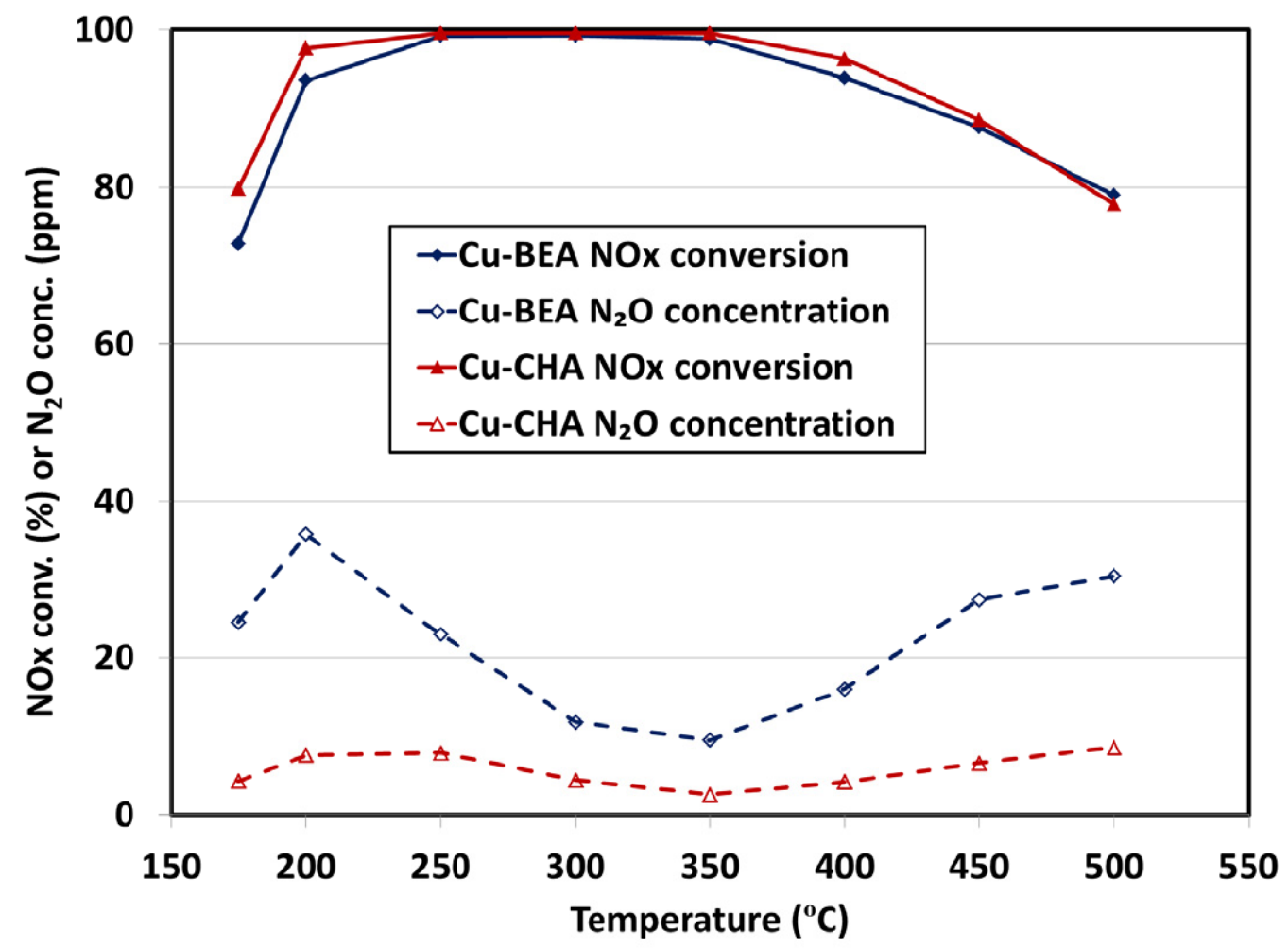

Fig. 1. Steady state NOx conversions and the corresponding $\mathrm{N}_{2} \mathrm{O}$ formation levels as a function of temperature for $\mathrm{Cu}-\mathrm{BEA}$ and $\mathrm{Cu}-\mathrm{CHA}$.

(SCR reaction conditions: 350 ppm NO, 350 ppm $\mathrm{NH}_{3}, 10 \% \mathrm{O}_{2}, 2.5 \% \mathrm{H}_{2} \mathrm{O}$, and balance $\mathrm{N}_{2}$, GHSV $=200,000 \mathrm{~h}^{-1}$ ) 


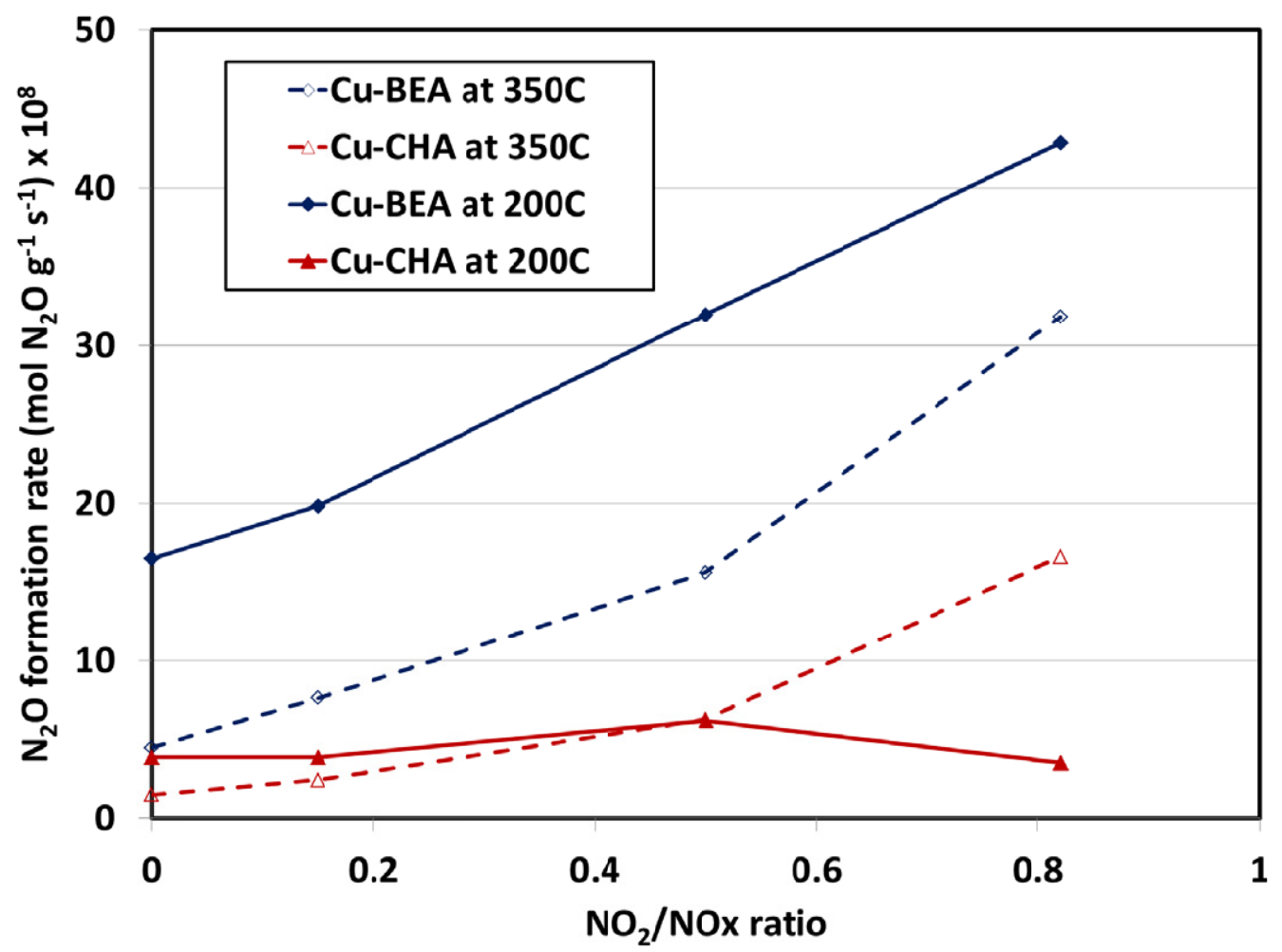

Fig. 2. Effect of $\mathrm{NO}_{2} / \mathrm{NOx}$ ratios in the feed gas on the $\mathrm{N}_{2} \mathrm{O}$ formation rates for $\mathrm{Cu}-\mathrm{BEA}$ and $\mathrm{Cu}-$ CHA.

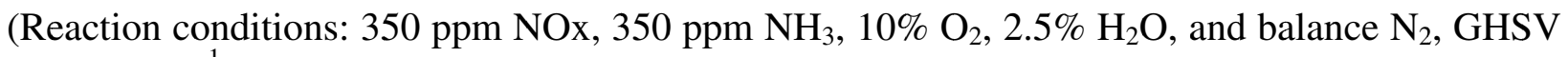
$=200,000 \mathrm{~h}^{-1}$ ) 

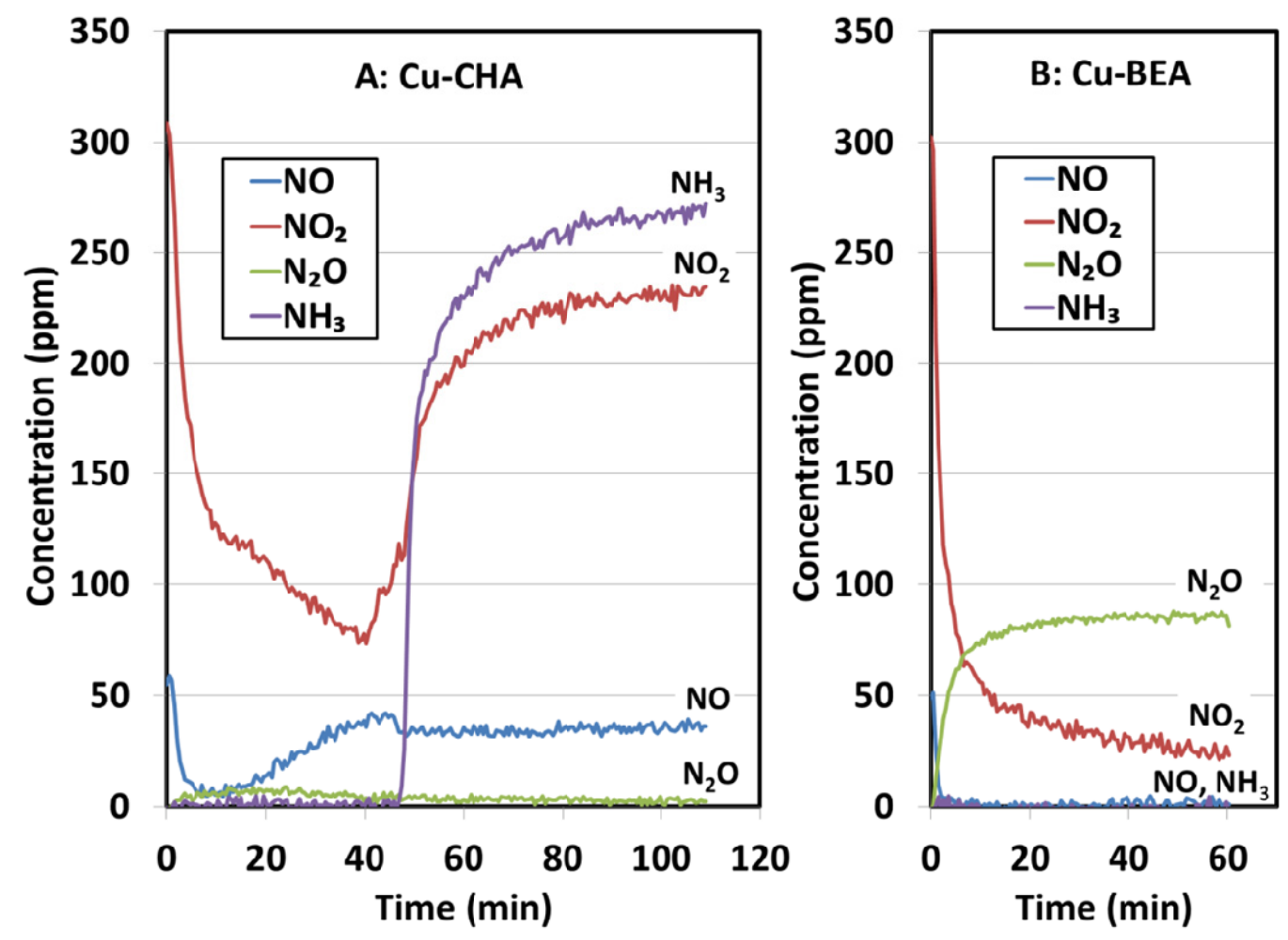

Fig. 3. Outlet concentrations of $\mathrm{NO}, \mathrm{NO}_{2}, \mathrm{~N}_{2} \mathrm{O}$, and $\mathrm{NH}_{3}$ downstream of (A) $\mathrm{Cu}-\mathrm{CHA}$ and (B) $\mathrm{Cu}-\mathrm{BEA}$.

(Reaction conditions: 350 ppm NOx (at an $\mathrm{NO}_{2} / \mathrm{NOx}=0.82$ ), $350 \mathrm{ppm} \mathrm{NH}_{3}, 10 \% \mathrm{O}_{2}, 2.5 \%$ $\mathrm{H}_{2} \mathrm{O}$, and balance $\mathrm{N}_{2}, \mathrm{GHSV}=200,000 \mathrm{~h}^{-1}$, temperature $=200{ }^{\circ} \mathrm{C}$ ) 


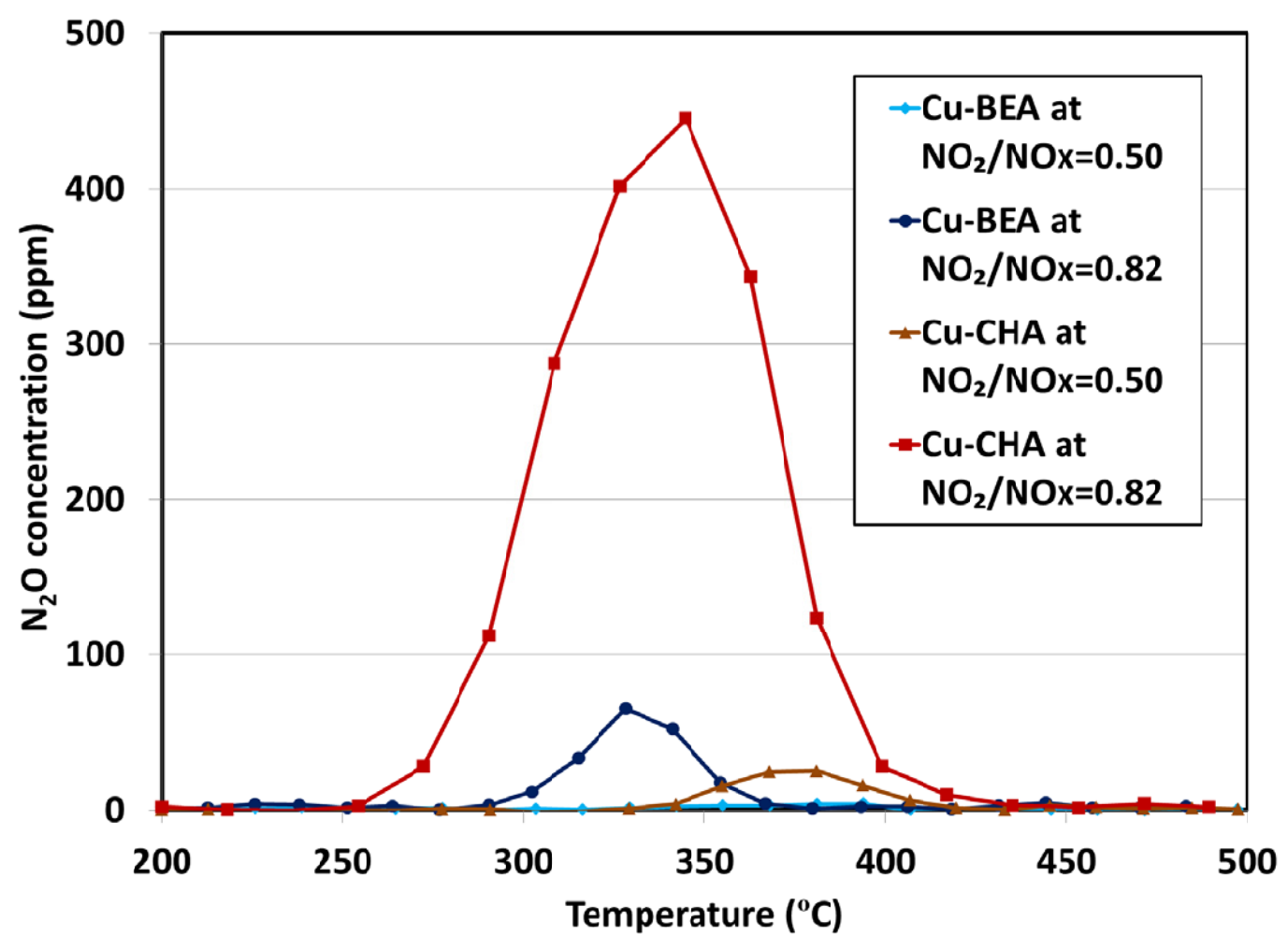

Fig. 4. $\mathrm{N}_{2} \mathrm{O}$ TPD of samples after SCR reaction at $200{ }^{\circ} \mathrm{C}$

(TPD was carried out in $10 \% \mathrm{O}_{2}, 2.5 \% \mathrm{H}_{2} \mathrm{O}$, and balance $\mathrm{N}_{2}$, at a GHSV $=200,000 \mathrm{~h}^{-1}$, with a ramping rate of $25^{\circ} \mathrm{C} / \mathrm{min}$; SCR reaction was performed in a feed of $350 \mathrm{ppm}$ NOx (at an

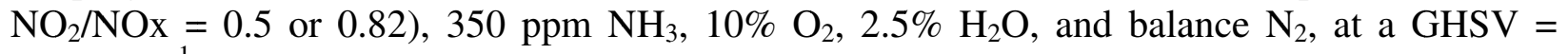
$200,000 \mathrm{~h}^{-1}$ ) 


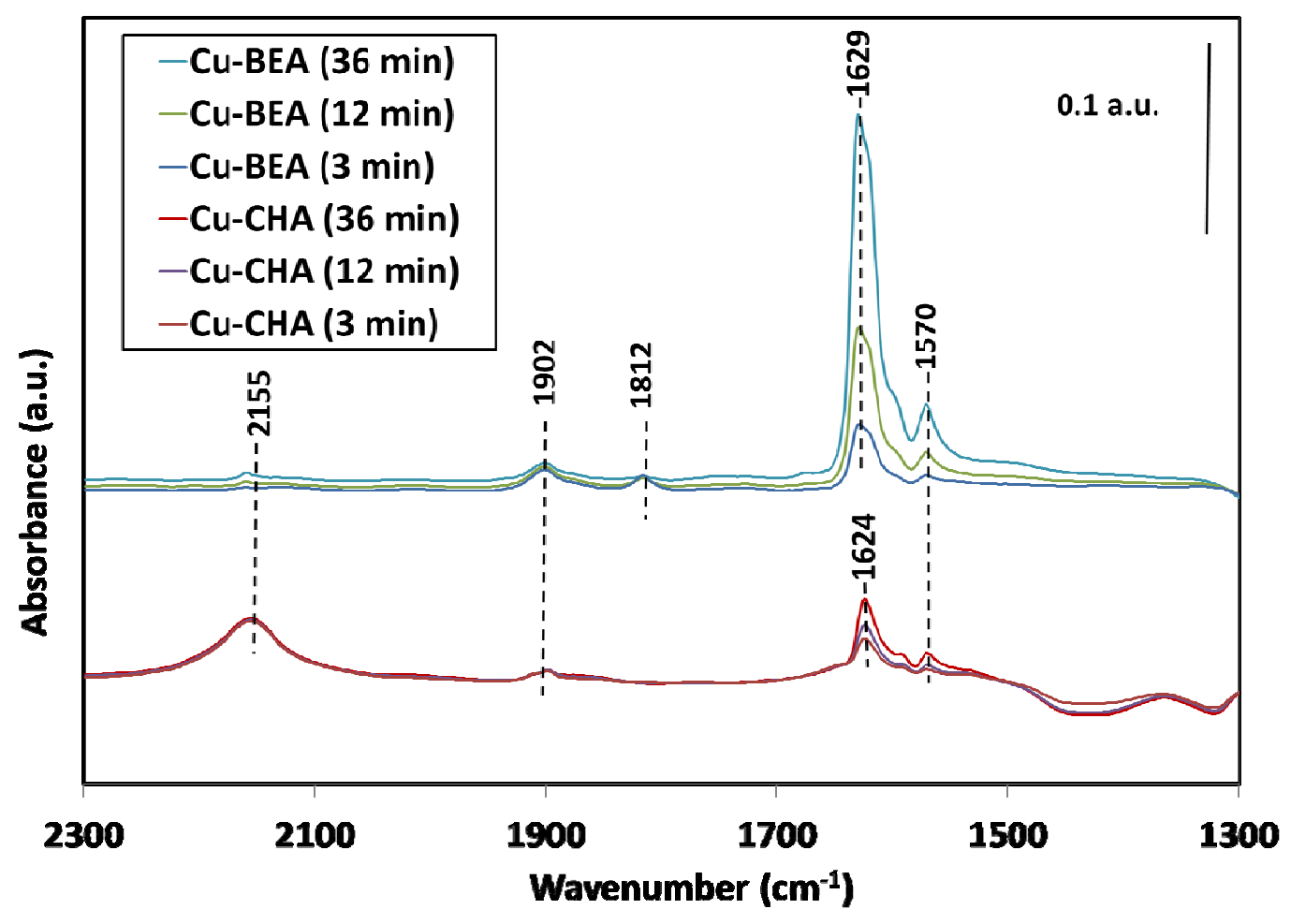

Fig. 5. In situ FTIR spectra at $200{ }^{\circ} \mathrm{C}$ of samples upon exposure to ( 0.15 Torr $\mathrm{NO}+1.35$ Torr $\mathrm{O}_{2}$ ) 


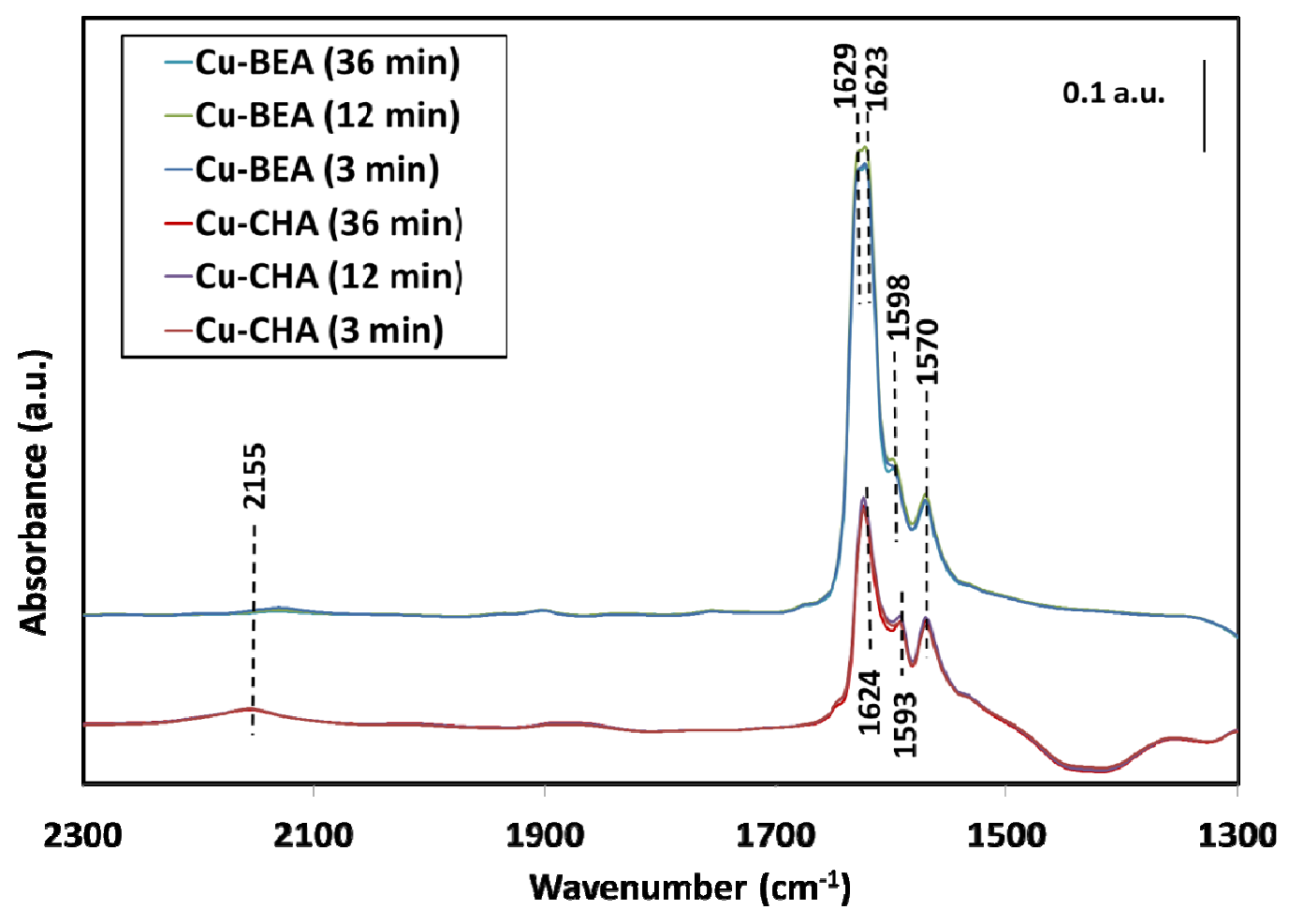

Fig. 6. In situ FTIR spectra at $200{ }^{\circ} \mathrm{C}$ of samples upon exposure to $\left(0.15\right.$ Torr $\mathrm{NO}_{2}+1.35$ Torr $\mathrm{O}_{2}$ ) 


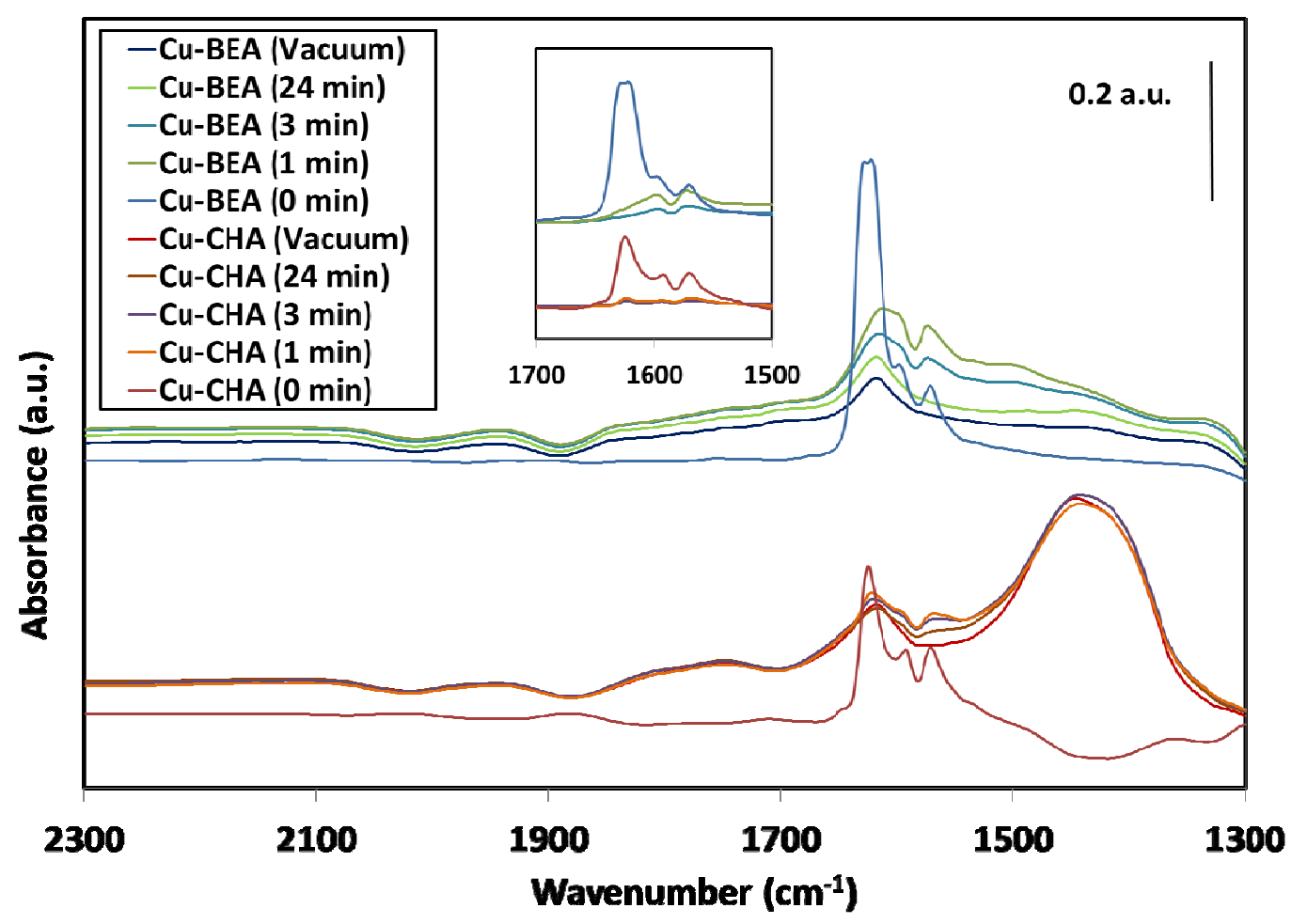

Fig. 7. In situ FTIR spectra at $200{ }^{\circ} \mathrm{C}$ of samples after nitrate pre-adsorption (labeled as (0 min)); and upon subsequent exposure to $\left(0.15\right.$ Torr ${ }^{15} \mathrm{NO}+0.6$ Torr $\mathrm{NH}_{3}+0.75$ Torr $\left.\mathrm{O}_{2}\right)$ for 1,3 , and $24 \mathrm{~min}$; and finally after evacuation (labeled as (Vacuum)). The (1 min) and the (3 min) spectra in the inset plot were further subtracted by the corresponding spectrum after 24 min exposure 


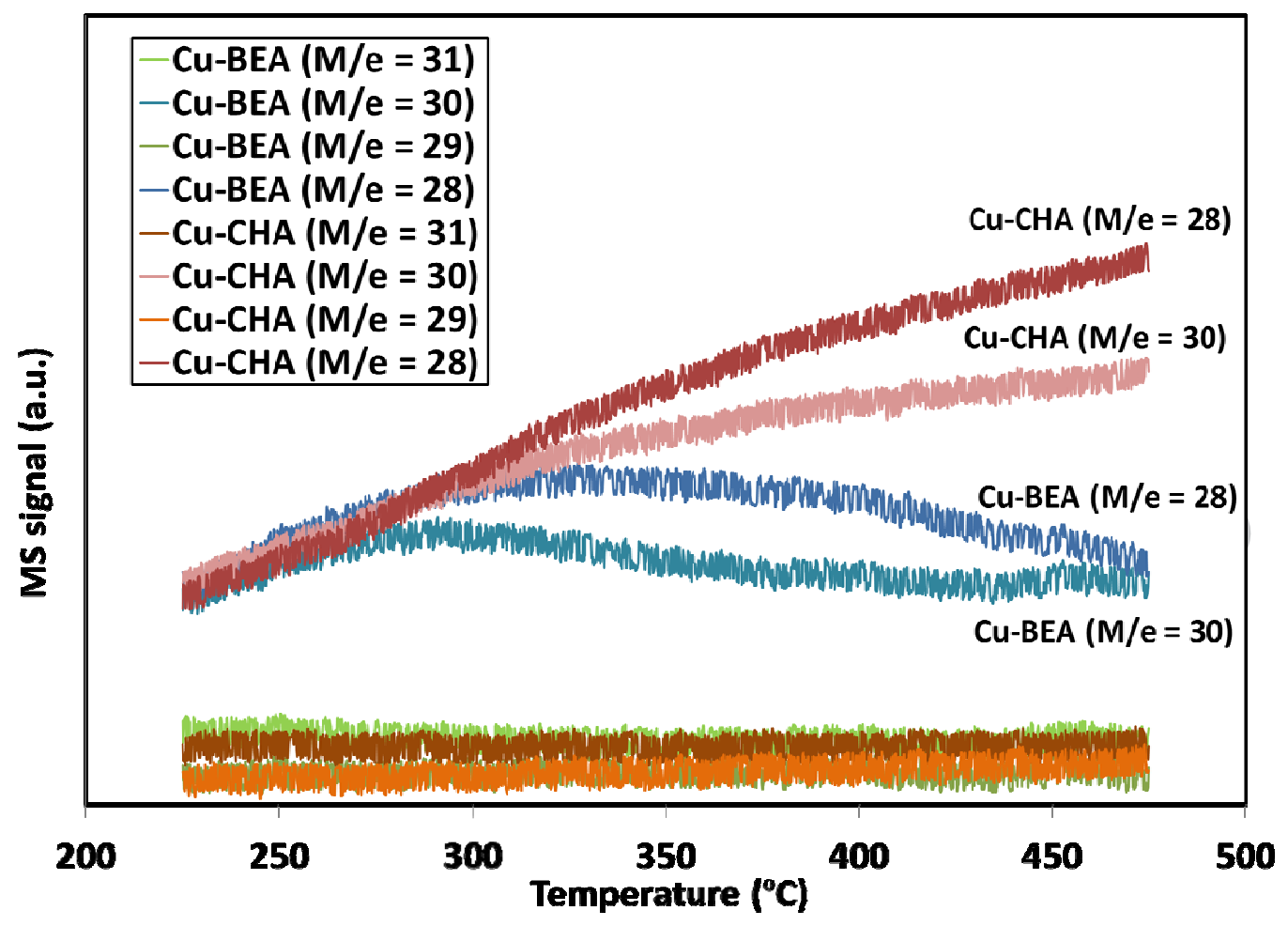

Fig. 8. Mass spectrometer signals in the TPD experiments after the samples were exposed to $\left(0.15\right.$ Torr $\mathrm{NO}_{2}+1.35$ Torr $\left.\mathrm{O}_{2}\right)$ followed by $\left(0.15\right.$ Torr ${ }^{15} \mathrm{NO}+0.6$ Torr $\mathrm{NH}_{3}+0.75$ Torr $\left.\mathrm{O}_{2}\right)$, both at $200{ }^{\circ} \mathrm{C}$ 


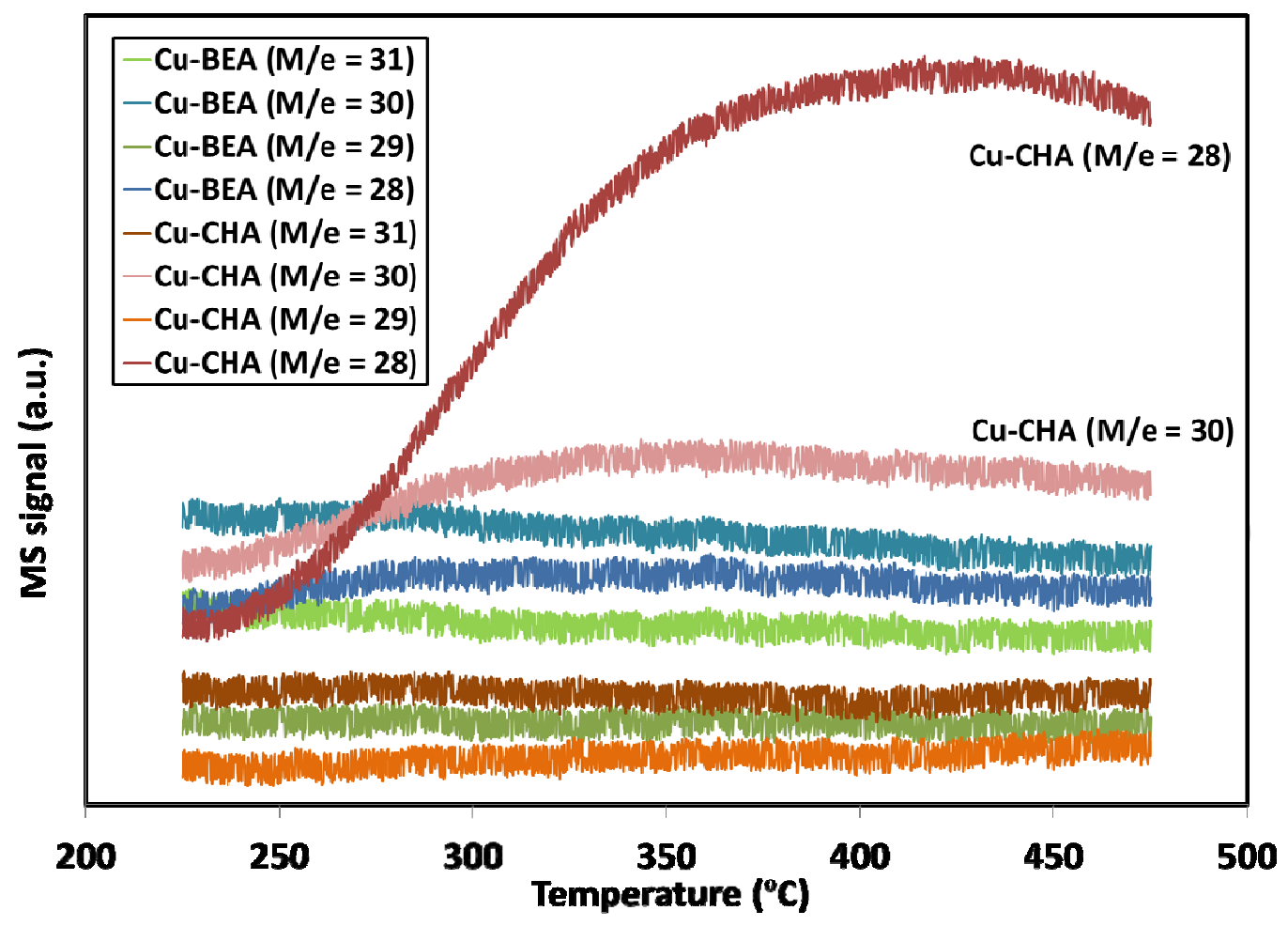

Fig. 9. Mass spectrometer signals in the TPD experiments after the samples were exposed to $\left(0.15\right.$ Torr $\mathrm{NO}_{2}+0.15$ Torr ${ }^{15} \mathrm{NO}+0.3$ Torr $\mathrm{NH}_{3}+0.9$ Torr $\left.\mathrm{O}_{2}\right)$ at $200{ }^{\circ} \mathrm{C}$ 


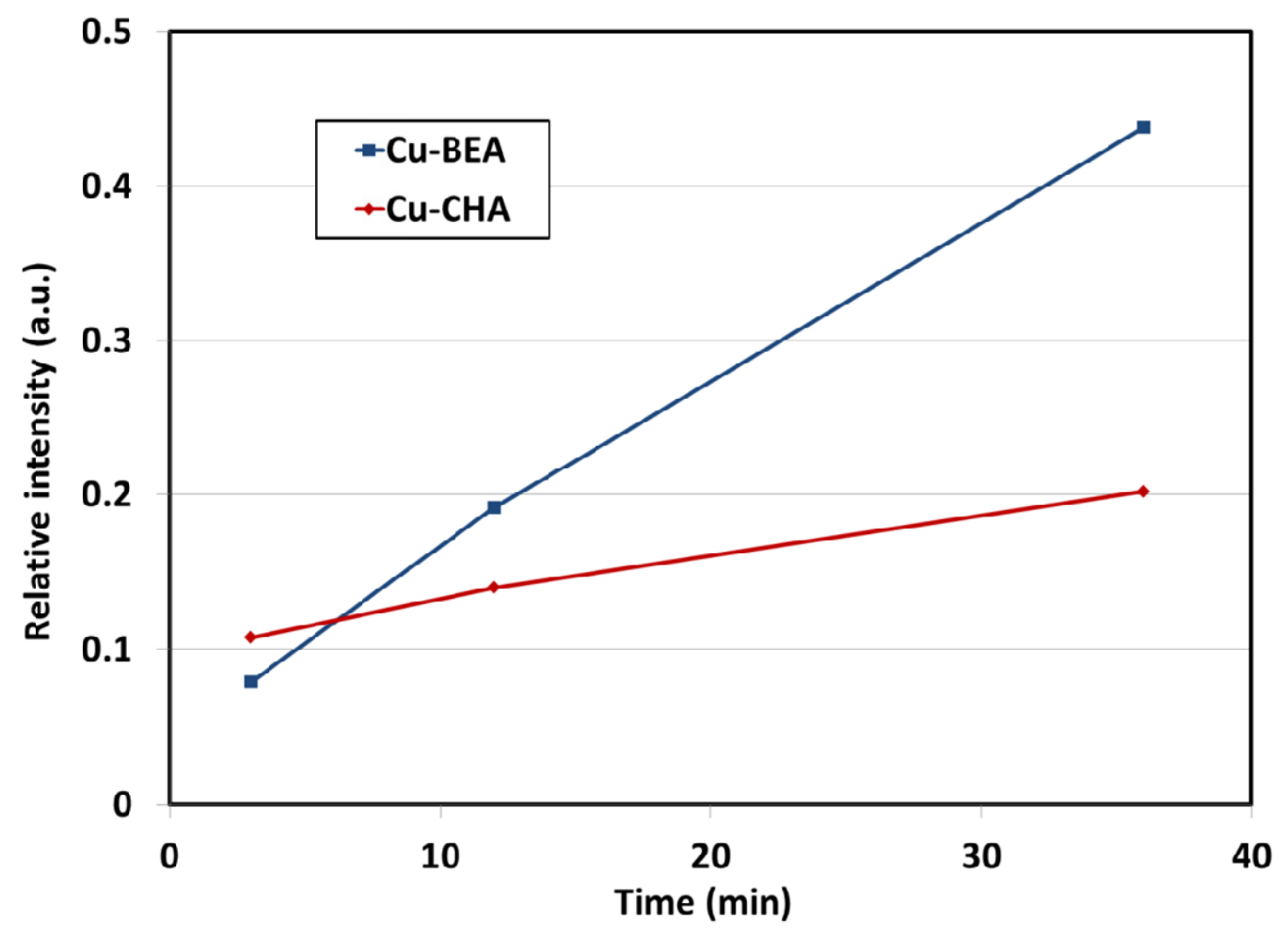

Fig. 10. Normalized intensities of IR bands at $1629 \mathrm{~cm}^{-1}$ (for Cu-BEA) and $1624 \mathrm{~cm}^{-1}$ (for $\mathrm{Cu}$ $\mathrm{CHA})$ as a function of exposure time in the $\left(0.15 \mathrm{Torr} \mathrm{NO}+1.35 \mathrm{Torr}_{2}\right)$ experiments of Fig. 5. 